\title{
DMS cycle in the marine ocean-atmosphere system - a global model study
}

\author{
S. Kloster, J. Feichter, E. Maier-Reimer, K. D. Six, P. Stier, and P. Wetzel \\ Max Planck Institute for Meteorology, Hamburg, Germany \\ Received: 22 July 2005 - Published in Biogeosciences Discussions: 22 August 2005 \\ Revised: 11 November 2005 - Accepted: 9 December 2005 - Published: 11 January 2006
}

\begin{abstract}
A global coupled ocean-atmosphere modeling system is established to study the production of dimethylsulfide (DMS) in the ocean, the DMS flux to the atmosphere, and the resulting sulfur concentrations in the atmosphere. The DMS production and consumption processes in the ocean are simulated in the marine biogeochemistry model HAMOCC5, embedded in a ocean general circulation model (MPI-OM). The atmospheric model ECHAM5 is extended by the microphysical aerosol model HAM, treating the sulfur chemistry in the atmosphere and the evolution of the microphysically interacting internally- and externally mixed aerosol populations.
\end{abstract}

We simulate a global annual mean DMS sea surface concentration of $1.8 \mathrm{nmol}^{-1}$, a DMS emission of $28 \mathrm{Tg}(\mathrm{S}) \mathrm{yr}^{-1}$, a DMS burden in the atmosphere of $0.077 \mathrm{Tg}(\mathrm{S})$, and a DMS lifetime of 1.0 days. To quantify the role of DMS in the atmospheric sulfur cycle we simulate the relative contribution of DMS-derived $\mathrm{SO}_{2}$ and $\mathrm{SO}_{4}^{2-}$ to the total atmospheric sulfur concentrations. DMS contributes $25 \%$ to the global annually averaged $\mathrm{SO}_{2}$ column burden. For $\mathrm{SO}_{4}^{2-}$ the contribution is $27 \%$.

The coupled model setup allows the evaluation of the simulated DMS quantities with measurements taken in the ocean and in the atmosphere. The simulated global distribution of DMS sea surface concentrations compares reasonably well with measurements. The comparison to $\mathrm{SO}_{4}^{2-}$ surface concentration measurements in regions with a high DMS contribution to $\mathrm{SO}_{4}^{2-}$ shows an overestimation by the model. This overestimation is most pronounced in the biologically active season with high DMS emissions and most likely caused by a too high simulated $\mathrm{SO}_{4}^{2-}$ yield from DMS oxidation.

Correspondence to: S. Kloster

(kloster@dkrz.de)

\section{Introduction}

Major uncertainties remain in the quantitative assessment of the climate response to anthropogenic forcing. Biogeochemical feedbacks, which may reduce or amplify the net impact of the anthropogenic forcing, are extremely important to the understanding and prediction of climate change (Lovelock et al., 1972). One possible negative biogeochemical feedback proposed by Charlson et al. (1987) involves the marine biosphere, the ocean and the atmosphere coupled through the marine biogenic sulfur compound dimethylsulfide (DMS).

DMS produced from phytoplankton is the most abundant form in which the ocean releases gaseous sulfur. In the atmosphere, DMS is oxidized to sulfate particles that alter the amount of solar radiation reaching the Earth's surface both by directly scattering solar energy and indirectly by acting as cloud condensation nuclei (CCN), thereby affecting the cloud albedo. The change in cloud albedo results in global temperature perturbations potentially affecting the productivity of the marine biosphere and hence the concentration of oceanic DMS. The oceanic and atmospheric processes involved in this multistep feedback mechanism are complex. Fundamental gaps remain in our understanding of key issues in this feedback process, in particular with regard to the processes that regulate the DMS seawater concentration (Andreae and Crutzen, 1997; Liss et al., 1997; Gabric et al., 2001; Vézina, 2004). Traditionally, the DMS cycle in the atmosphere and in the ocean have been assessed independently. As a consequence, it has not been possible to assess the strength of the proposed feedback or even to anticipate if global warming will result in an increase or a decrease of DMS emissions. However, significant progress has been made to understand many of the included mechanisms.

Enzymatic decomposition of dimethylsulfonium propionate (DMSP) is the primary source of DMS in seawater with DMSP being released from phytoplankton by a variety of mechanisms. The biological function of DMSP,

C 2006 Author(s). This work is licensed under a Creative Commons License. 
and especially of its degradation to DMS, is still not clear. It has been suggested that the physiological function of DMSP is related to maintaining intercellular osmotic pressure (Vairavamurthy et al., 1985). Other suggested physiological functions of DMSP in marine algae are that it may act as a cryoprotectant (Kirst et al., 1991; Stefels, 2000) and serve as an antioxidant system (Suda et al., 2002).

DMSP is widespread among taxa but seems to be particularly abundant in specific groups, including coccolithophorids like Emiliania huxleyi. Other groups, like diatoms, are generally poor producers of DMSP (Keller et al., 1989). Among other factors, DMSP release into the water is assumed to be controlled by phytoplankton senescence (Nguyen et al., 1990; Kwint and Kramer, 1995), viral lysis of phytoplankton cells (Malin et al., 1998) and zooplankton grazing (Dacey and Wakeham, 1986). Dissolved DMSP is degraded to DMS via enzymatic cleavage carried out by algal or bacterial DMSP lyase (Steinke et al., 2002; Yoch et al., 1997). A large fraction of DMSP is utilized by bacteria and does not lead to the production of DMS (Kiene, 1996). Kiene et al. (2000) hypothesized that the sulfur-demand of bacteria determines the proportion on which DMSP is processed through this demethylation pathway, rather than being converted by enzymatic degradation to DMS.

Consumption by bacteria is the major sink for DMS in seawater (Kiene and Bates, 1990; Dacey and Wakeham, 1986). Chemical oxidation of DMS to dimethyl sulfoxide (DMSO) in seawater and ventilation to the atmosphere contribute only a minor part to the total DMS removal in seawater (e.g. Shooter and Brimblecombe, 1989; Kieber et al., 1996; Bates et al., 1994; Gabric et al., 1993).

DMS sea-air fluxes may vary by orders of magnitude in space and time. Although there are no direct means of measuring DMS sea-air flux, it can be estimated from the DMS sea surface concentration combined with an empirically determined exchange rate. Parameterization of DMS sea-air exchange rates have been investigated in several studies (e.g. Wanninkhof, 1992; Wanninkhof and McGillis, 1999; Liss and Merlivat, 1986; Nightingale et al., 2000; McGillis et al., 2000; Zemmelink et al., 2002). According to Nightingale et al. (2000), the uncertainties associated with the exchange rate are approximately $50 \%$.

Many aspects of the DMS oxidation in the atmosphere are poorly understood (e.g. Campolongo et al., 1999; Andreae and Crutzen, 1997). It is well-established that OH reacts with DMS and that $\mathrm{SO}_{2}$ and methane sulfonic acid (MSA) are among the major reaction products (e.g. Capaldo and Pandis, 1997). It is also known that $\mathrm{NO}_{3}$ and halogen oxide radicals (e.g. $\mathrm{BrO}, \mathrm{IO}, \mathrm{ClO}$ ) react with DMS in the atmosphere, but the importance of these reactions is even less well-known (Sayin and McKee, 2004).

A key link in the proposed feedback between DMS and climate is the nucleation of DMS-derived sulfuric acid into new particles and eventually the formation of new cloudforming particles (Charlson et al., 1987). The nucleation ability of DMS-derived sulfuric acid in the marine boundary layer is still under debate (Yoon and Brimblecombe, 2002). Measurements over the South Atlantic, at Cape Grim, and at Amsterdam Island show a strong correlation between DMS emission and the concentration of total aerosol particles and CCN (Putaud et al., 1993; Andreae et al., 1995, 1999; Ayers and Gillett, 2000). However, such findings are by no means generally applicable. Several investigators found no or only sporadic correlation between DMS and non-sea-salt sulfate, CN or CCN (Bates et al., 1992; Berresheim et al., 1993).

DMS and its oxidation products in the atmosphere are short-lived species. Therefore, it is necessary to resolve the temporal and spatial distribution of the DMS sea surface concentration on a global scale to investigate its impact on the climate system. Several studies attempted to build climatologies of the global distribution of DMS in the sea surface water. Belviso et al. (2004a) recently compared seven global DMS monthly climatologies (Kettle et al., 1999; Kettle and Andreae, 2000; Anderson et al., 2001; Aumont et al., 2002; Simó and Dachs, 2002; Chu et al., 2003; Belviso et al., $2004 \mathrm{~b})$. For the zonal and annual mean they found differences ranging from $50 \%$ in the tropics to $100 \%$ in high latitudes. The studies of Kettle et al. (1999); Kettle and Andreae (2000); Anderson et al. (2001); Simó and Dachs (2002) all rely on the Kettle et al. (1999) database which consists of almost 16000 DMS sea surface measurements. Kettle et al. (1999) and Kettle and Andreae (2000) derived monthly mean maps by a compilation of the measurements included in the database. Anderson et al. (2001) and Simó and Dachs (2002) used only the data points from the Kettle et al. (1999) database with concurrent chlorophyll $\alpha$ and DMS sea surface measurements and extended the resulting database by climatological information about incoming light and nutrient abundance or by information about the mixed layer depth (MLD), respectively. From the extended database they derived nonlinear relationships to predict DMS sea surface concentrations. Aumont et al. (2002) and Belviso et al. (2004b) used a prognostic nonlinear parameterization to compute DMS sea surface concentrations from chlorophyll $\alpha$ concentrations together with an index of community structure of marine phytoplankton derived from measurements taken at several DMS surveys. Only the approach of Chu et al. (2003) uses a prognostic biogeochemical formulation for DMS production and DMS removal in the ocean based on the regional work of Gabric et al. (1993).

Several atmospheric modeling studies simulate the DMS gas exchange between atmosphere and ocean based on prescribed DMS sea surface concentrations. The Kettle and Andreae (2000) climatology of the DMS seawater concentration is widely used in global atmospheric models (e.g. Boucher and Pham, 2002; Jones et al., 2001; Berglen et al., 2004; Gondwe et al., 2003; Rotstayn and Lohmann, 2002). The response of the DMS emission to climate change can then only be assessed in models with prescribed DMS sea surface concentrations through changes in the sea-air exchange 
rate which varies with wind speed and temperature. Penner et al. (2001) showed a small increase in simulated DMS emissions between 2000 and 2100 (from $26.0 \mathrm{Tg}(\mathrm{S}) \mathrm{yr}^{-1}$ to 27.7 $\left.\mathrm{Tg}(\mathrm{S}) \mathrm{yr}^{-1}\right)$ using a constant DMS sea surface concentration field (Kettle et al., 1999) combined with a constant monthly climatological ice cover. The gas exchange rates were calculated interactively in the simulation based on wind speed and sea surface temperature. However, DMS sea surface concentrations are controlled by marine biology which is affected by climate variables such as solar radiation, temperature and ocean physics. These variables are likely to change under changing climate conditions.

Changes in climate will lead to changes in the emission of other components that are linked to the DMS cycle, e.g. sea salt aerosols (Gong and Barrie, 2003), emissions associated with organic aerosols (O'Dowd et al., 1999) and dust emissions (Tegen et al., 2004). Stier et al. (2004) showed in a global microphysical aerosol modeling study that specific emission changes cause changes in aerosol cycles of other components confirming a microphysical coupling between the different aerosol cycles. To account for these effects, the DMS-climate feedback has to be studied as a part of the complex global aerosol system.

To assess the role of DMS in the climate system, it is essential to treat the DMS cycle interactively in the oceanatmosphere system, as the proposed DMS-climate feedback is a multi-compartment feedback. This requires a coupled ocean-atmosphere model with prognostic treatment of the marine DMS and the atmospheric sulfur cycle. This study introduces such a comprehensive model, describes the simulated multi-compartment sulfur cycle and provides an evaluation with available measurements. Additionally, simulated DMS sea surface concentrations are compared to DMS concentrations derived with the recently developed Simó and Dachs (2002) algorithm. Particular attention is given to the implementation of a formulation of DMS production and degradation in the ocean in order to simulate dynamically consistent maps of DMS sea surface concentrations, which provides the basis for an assessment of interactions between marine DMS and the atmosphere.

\section{Model description}

The model used in the experiment is a coupled atmosphereocean general circulation model (AOGCM). The AOGCM consists of sub-models which correspond to the atmosphere (ECHAM5) and the ocean (MPI-OM). The atmospheric model includes a microphysical aerosol model (HAM) which simulates the evolution of an ensemble of microphysically interacting internally- and externally mixed aerosol populations as well as their size-distribution and composition. Embedded in the ocean model is a marine biogeochemistry model (HAMOCC5) which has been extended by a formula- tion of the DMS cycle in the ocean. The single model components are briefly described in the following sections.

\subsection{The MPI-OM general circulation model}

The ocean component is the Max-Planck-Institute ocean model (MPI-OM) (Marsland et al., 2003). MPI-OM is a $\mathrm{z}$-coordinate global general circulation model based on the primitive equations for a Boussinesq-fluid on a rotating sphere. The transport is computed with a total variation diminishing (TVD) scheme (Sweby, 1984). It includes parameterizations of sub grid scale mixing processes like isopycnal diffusion of the thermohaline fields, eddy induced tracer transport following Gent et al. (1995), and a bottom boundary slope convection scheme. The model treats a free surface and a state of the art sea ice model with viscous-plastic rheology and snow (Hibler, 1979). The model works on a curvilinear orthogonal $\mathrm{C}$-grid. In this study, we use a nominal resolution of $1.5^{\circ}$ at the equator with one pole located over Greenland and the other over Antarctica. In the vertical, the model has 40 levels with level thickness increasing with depth. 8 layers are located within the upper $90 \mathrm{~m}$ and 20 layers within the upper $600 \mathrm{~m}$.

\subsection{The marine biogeochemistry model HAMOCC5}

The marine biogeochemistry component is the Hamburg Oceanic Carbon Cycle Model (HAMOCC5) (Maier-Reimer et al., 2005; Six and Maier-Reimer, 1996; Maier-Reimer, 1993). HAMOCC5 simulates the biogeochemical tracers in the oceanic water column and the sediment. The model is coupled online to the circulation and diffusion of the MPI-OM ocean model and runs with the same time step and resolution. The eco-system model is based on nutrients, phytoplankton, zooplankton and detritus (NPZD-type) as described in Six and Maier-Reimer (1996). In addition, new elements like nitrogen, dissolved iron and dust are accounted for and new processes like denitrification, nitrogen fixation, dissolved iron uptake and release by biogenic particles, and dust deposition and sinking are implemented as described in detail in Wetzel (2004). The dust deposition to the ocean surface is calculated online in the ECHAM5-HAM submodel and passed to the marine biogeochemistry model HAMOCC5 once per day. Bioavailable iron is released in the surface layer immediately from the freshly deposited dust.

\subsubsection{DMS formulation in the marine biogeochemistry} module HAMOCC5

The DMS formulation in HAMOCC5 is derived from the formulation originally developed for a former version of the marine biogeochemistry module (HAMOCC3.1, Six and MaierReimer, 1996; Six and Maier-Reimer, 2006 ${ }^{1}$ ).

\footnotetext{
${ }^{1}$ Six, K. D. and Maier-Reimer, E.: What controls the oceanic dimethylsulfide (DMS) cycle? A modeling approach, Global Bio-
} 
Table 1. Parameters for DMS formulation in HAMOCC5. The parameters are derived from an optimization procedure of HAMOCC5 using DMS sea surface concentration measurements from the Kettle and Andreae (2000) database.

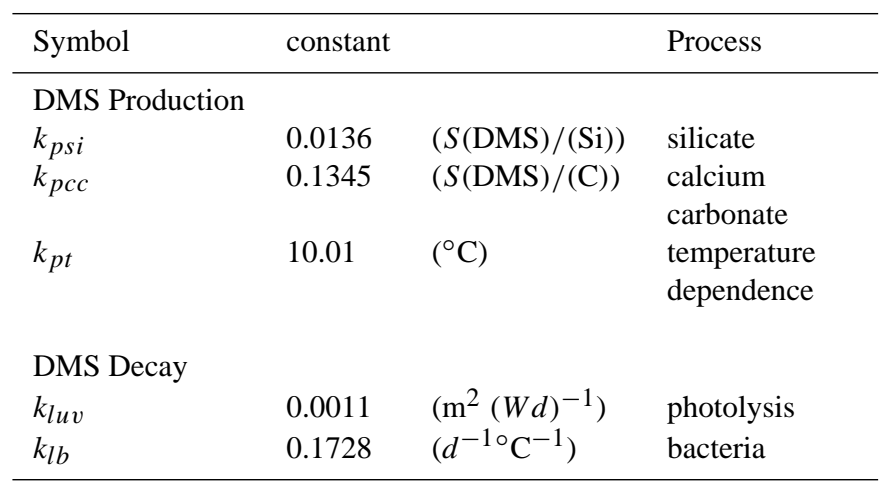

The formulation for DMS production in the ocean assumes that DMS is produced ( $\left.\mathrm{DMS}_{\text {prod }}\right)$ when phytoplankton cells are destroyed due to senescence or grazing processes. The DMS decay occurs via consumption by bacteria $\left(\mathrm{DMS}_{\mathrm{bac}}\right)$, chemical oxidation to DMSO (DMS $\mathrm{UV}$ ) and ventilation to the atmosphere $\left(\mathrm{DMS}_{\text {flux }}\right)$.

$$
\frac{\mathrm{d}[\mathrm{DMS}]}{\mathrm{dt}}=\mathrm{DMS}_{\mathrm{prod}}-\mathrm{DMS}_{\mathrm{bac}}-\mathrm{DMS}_{\mathrm{UV}}-\mathrm{DMS}_{\mathrm{flux}}
$$

Here only dissolved DMS is considered. DMSP as the precursor of DMS in the ocean is not taken into account explicitly because very little is known about the actual processes that lead to the reduction of DMSP to DMS (Kiene et al., 2000). Moreover, only few measurements of DMSP concentrations in the ocean are available which makes an evaluation not feasible.

HAMOCC5 was developed to simulate the carbon chemistry in the ocean. To simulate the vertical alkalinity distribution it separates between the export of particulate silicate and calcium carbonate (export $t_{\mathrm{sil}}$ and export $\mathrm{CaCO}_{3}$, respectively). The resulting vertical alkalinity distribution compares well with available measurements (Wetzel et al., 2005; Wetzel, 2004). By separating the export into the export of calcium carbonate and the export of silicate, HAMOCC5 distinguishes indirectly between the two phytoplankton groups the diatoms which form opal frustels, and the coccolithophorids which build skeletons made of calcium carbonate. It is assumed that fast growing diatoms consume nutrients as long as silicate is available. Therefore, the export of organic carbon is linked to silicate until silicate is depleted in the ocean. After depletion of silicate the phytoplankton growth is carried out by coccolithophorids, resulting in the export of calcium carbonate. The simulated ratio of calcium carbonate

geochem. Cycles, submitted, 2006. to organic carbon export is tuned to be 0.06 on global average in order to simulate a realistic alkalinity distribution (Wetzel, 2004; Sarmiento et al., 2002). This distinction between diatoms and coccolithophorids is important, as they are known to differ markedly in terms of their cellular DMSP content, and hence their ability for producing DMS (Keller et al., 1989). We utilize the distinction between silicate and calcium carbonate export to simulate the DMS production as follows:

$$
\mathrm{DMS}_{\mathrm{prod}}=f(T) \times\left(k_{\mathrm{psi}} \times \operatorname{export}_{\mathrm{sil}}+k_{p c c} \times \operatorname{export}_{\mathrm{CaCO}_{3}}\right)(2)
$$

$k_{\mathrm{psi}}$ and $k_{p c c}$ are the respective scaling factors defined in Table 1 . The function $f(T)$ accounts for the observed temperature dependence of intercellular DMSP concentrations. Under low temperature conditions, e.g. in polar regions, the DMSP content in phytoplankton cells is higher than under temperate conditions (Baumann et al., 1994). This effect is parameterized as follows:

$f(T)=\left(1+\frac{1}{\left(T+k_{p t}\right)^{2}}\right)$

with $T$ in ${ }^{\circ} \mathrm{C}, k_{p t}$ scales the temperature dependency (Table 1).

The DMS destruction processes are formulated as follows: The destruction of DMS by photo-oxidation to DMSO depends on the solar radiation at the surface (Shooter and Brimblecombe, 1989; Brimblecombe and Shooter, 1986; Kieber et al., 1996). The incident solar radiation $I_{0}$ is attenuated in HAMOCC 5 by water and phytoplankton as a function of depth $(z)$ according to the equation:

$I_{z}=I_{0} \times e^{-\left(k_{w}+k_{c h l}\right) \times z}$

The attenuation coefficient for pure water is chosen to be $k_{w}=0.04 \mathrm{~m}^{-1}$. Light attenuation by phytoplankton is assumed to be a linear function of the chlorophyll concentration $k_{\mathrm{chl}}=0.03[\mathrm{CHL}] \mathrm{m}^{-1}$, with the chlorophyll concentration [CHL] given in $\mathrm{mgl}^{-1}$. The chlorophyll concentration is computed from the modeled phytoplankton concentration with a fixed chlorophyll to carbon ratio of 1:60. The incident surface radiation $\left(\mathrm{W} \mathrm{m}^{-2}\right)$ is calculated interactively, including the effects of clouds and aerosols, in the ECHAM5-HAM model. The decay of DMS by photo-oxidation is then formulated as follows:

$\mathrm{DMS}_{\mathrm{UV}}=k_{\mathrm{luv}} \times I_{z} \times[\mathrm{DMS}]$

$k_{\text {luv }}$ is the respective scaling factor defined in Table 1. DMS destruction due to consumption by bacteria is assumed to be temperature dependent:

$\mathrm{DMS}_{\mathrm{bac}}=k_{l b} \times(T+3) \times.[\mathrm{DMS}] \times f([\mathrm{DMS}])$

with $T$ in ${ }^{\circ} \mathrm{C} . k_{l b}$ denotes the scaling factor for the consumption process by bacteria. Observations suggest that consumption by bacteria appears to be less efficient in areas with low 
DMS concentrations (Kiene and Bates, 1990). We parameterize this variation with a saturation function:

$f([\mathrm{DMS}])=\left(\frac{[\mathrm{DMS}]}{k_{c b}+[\mathrm{DMS}]}\right)$

$k_{c b}$ is set to $10 \mathrm{nmol}^{-1}$ which ensures an almost linear behavior for low DMS concentrations. For the atmosphere, the most important DMS loss mechanism in seawater is the loss due to sea-air exchange. For the sea-air exchange calculation we neglect the DMS concentration in the atmosphere, as it is small compared to the DMS sea surface concentration, and formulate the DMS sea-air exchange as:

$\mathrm{DMS}_{\text {flux }}=k_{\text {sea }- \text { air }} \times[\mathrm{DMS}]$

$k_{\text {sea-air }}$ denotes the sea-air exchange rate. We choose the formulation after Wanninkhof (1992):

$k_{\text {sea-air }}=0.31 \times w_{10 \mathrm{~m}}^{2} \times\left(\frac{S C}{660}\right)^{-\frac{1}{2}}$

where $w_{10}$ is the $10 \mathrm{~m}$ wind speed and $S C$ the Schmidt number for DMS which is calculated analogous to Saltzman et al. (1993).

The undetermined parameters are derived from a fit of the simulated DMS sea surface concentrations to observed DMS sea surface concentrations. Kettle and Andreae (2000) compiled a database of almost 16000 DMS sea surface concentration measurements. Thereby, the original database (Kettle et al., 1999) was updated by new measurements. We utilized the updated database for an optimization of the parameters in the proposed DMS formulation. Therefore, the data points are distributed onto the ocean grid cells on a monthly mean basis. The DMS grid value is taken to be the average of the individual monthly mean measurements within the grid cell. Since the data coverage is very sparse and the partitioning into monthly means is rather arbitrary, we extrapolated the resulting DMS sea surface concentration for a single grid box to the adjacent grid boxes and also took values from the adjacent months into account for the monthly splitting. Due to computational constraints it is not feasible to conduct the optimization process within the full coupled AOGCM. To derive the DMS scaling parameters, we use an offline version of the ocean model (MPI-OM/HAMOCC5) forced by NCEP/NCAR reanalysis data (Kalnay et al., 1996). The model setup is described in detail in Wetzel et al. (2005). From this simulation we arbitrarily choose the year 1995 for the optimization process of the DMS scaling parameters. Periodically repeating the simulation with NCEP/NCAR forcing fields for the year 1995, we calculate global value deviation fields of the modeled DMS sea surface concentration and the DMS sea surface map, generated from the Kettle and Andreae (2000) database. Thereby, we take only ocean grid boxes into account with an ocean depth greater than $300 \mathrm{~m}$. Regions with a shallower depth, like the North Sea, are not well captured by the model. In these regions the Kettle and Andreae (2000) database includes a disproportional high number of measurements. To avoid a bias in the optimization process towards these measurements, these grid boxes are excluded. We define a cost function as the global annual sum of the deviation fields. In a series of two year runs, starting with the same initial conditions, this cost function is minimized by changing the five free parameters $\left(k_{p s i}, k_{p c c}\right.$, $k_{p t}, k_{l u v}, k_{l b}$ ) of the DMS formulation sequentially by plus or minus $5 \%$. The cost function is then calculated during every second model year. The parameters are changed along the gradient leading to a minimum of the cost function. The task of this global optimization process is to find the global minimum of the cost function. However, we cannot exclude that this optimization process leads to a local minimum, which is a general problem in optimization procedures. The resulting parameters of the optimization parameters are compiled in Table 1.

\subsection{The ECHAM5 general circulation model}

The atmospheric component is the ECHAM5 model (Roeckner et al., 2003) with the current standard resolution of 31 vertical levels on a hybrid sigma-pressure coordinate system up to a pressure level of $10 \mathrm{hPa}$. Prognostic variables are vorticity, divergence, surface pressure, temperature, water vapor, cloud water and cloud ice. Except for the water and chemical components, the prognostic variables are represented by spherical harmonics with triangular truncation at wavenumber 63 (T63). Physical processes and nonlinear terms are calculated on a Gaussian grid with a nominal resolution of $1.8^{\circ}$ in longitude and latitude. For the advection of water vapor, cloud liquid water, cloud ice and tracer components, a flux form semi-Lagrangian transport scheme (Lin and Rood, 1996) is applied. Cumulus convection is based on the mass flux scheme after Tiedtke (1989) with modifications according to Nordeng (1994). The cloud microphysical scheme (Lohmann and Roeckner, 1996) consists of prognostic equations for cloud liquid water and cloud ice. The cloud cover is predicted with a statistical scheme including prognostic equations for the distribution moments (Tompkins, 2002). The transfer of solar radiation is parameterized after Fouquart and Bonnel (1980) and the transfer of longwave radiation after Morcrette et al. (1998).

\subsection{The HAM aerosol model}

The ECHAM5 model has been extended by a complex microphysical aerosol model HAM, described in detail in Stier et al. (2005). The aerosol spectrum is represented by the superposition of seven log-normal distributions. These seven aerosol modes can be described by three moments: the aerosol number, the number median radius, and the standard deviation. The seven modes are divided into four geometrical size classes (nucleation, Aitken, accumulation and coarse mode). Three of the modes include only insoluble 


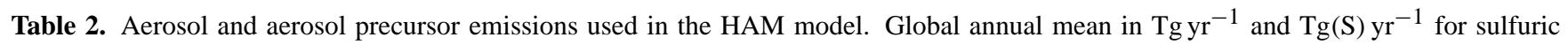
species.

\begin{tabular}{|c|c|c|c|}
\hline Species & Source & Reference & $\operatorname{Tg~yr}^{-1}$ \\
\hline \multirow[t]{2}{*}{ DMS } & Terrestial Biosphere & Pham et al. (1995) & 0.3 \\
\hline & Marine Biosphere & HAMOCC5 & 27.6 \\
\hline \multirow[t]{4}{*}{$\mathrm{SO}_{2}$} & Volcanoes & Andres and Kasgnoc (1998) & 14.6 \\
\hline & & Halmer et al. (2002) & \\
\hline & Vegetation Fires & van der Werf et al. (2003) & 2.1 \\
\hline & $\begin{array}{l}\text { Industry, Fossil-Fuel, } \\
\text { Bio-Fuels }\end{array}$ & Cofala et al. (2005) & 54.2 \\
\hline Total sulfur & & & 99.0 \\
\hline \multirow[t]{2}{*}{$\mathrm{BC}$} & Vegetation Fires & van der Werf et al. (2003) & 3.0 \\
\hline & $\begin{array}{l}\text { Fossil-Fuel and } \\
\text { Bio-Fuels }\end{array}$ & Bond et al. (2004) & 4.7 \\
\hline Total BC & & & 7.7 \\
\hline \multirow[t]{3}{*}{ POM } & Vegetation Fires & van der Werf et al. (2003) & 34.7 \\
\hline & Biogenic & Guenther et al. (1995) & 19.1 \\
\hline & $\begin{array}{l}\text { Fossil-Fuel and } \\
\text { Bio-Fuels }\end{array}$ & Bond et al. (2004) & 12.5 \\
\hline Total POM & & & 66.3 \\
\hline SSA & Wind driven & Schulz et al. (2004) & 5868.6 \\
\hline DU & Wind driven & Tegen et al. (2002) & 1060.6 \\
\hline
\end{tabular}

compounds, four of the modes contain at least one soluble compound. Aerosol compounds considered are sulfate (SU), black carbon (BC), particulate organic mass (POM), sea salt (SSA), and mineral dust (DU). HAM consists of a microphysical core M7, an emission module, a sulfur chemistry scheme, a deposition module, and a radiation module defining the aerosol radiative properties.

The microphysical core M7 (Vignati et al., 2004) treats the aerosol dynamics and thermodynamics. Processes considered are coagulation among the modes, condensation of gas-phase sulfuric acid on the aerosol surface, the binary nucleation of sulfate, and water uptake.

The emission of mineral dust and sea salt is calculated interactively according to the scheme of Tegen et al. (2002) and Schulz et al. (2004), respectively. DMS emissions are calculated online in the marine biosphere submodel HAMOCC5. For the other aerosol compounds, emission strengths, emission size distribution and emission height are based on the AEROCOM (Aerosol Model Inter-Comparison, http://nansen.ipsl.jussieu.fr/AEROCOM) emission inventory for the year 2000 (Dentener et al., 2006 ${ }^{2}$ ). The emission

\footnotetext{
${ }^{2}$ Dentener, F., Kinne, S., Bond, T., Boucher, O., Cofala, J., Generoso, S., Ginoux, P., Gong, S., Hoelzemann, J. J., Ito, A., Marelli, L., Penner, J., Putaud, J.-P., Textor, C., Schulz, M., van der Werf, G., and Wilson, J.: Emissions of primary aerosol and aerosol pre-
}

strength for all aerosol compounds is summarized in Table 2.

The sulfur chemistry module (Feichter et al., 1996) treats DMS, $\mathrm{SO}_{2}$ and $\mathrm{SO}_{4}^{2-}$ as prognostic variables. In the gas phase, $\mathrm{SO}_{2}$ and DMS are oxidized by hydroxyl $(\mathrm{OH})$ during the day. Additionally, DMS reacts with nitrate radicals $\left(\mathrm{NO}_{3}\right)$ at night. Reaction products are $\mathrm{SO}_{2}$ and $\mathrm{SO}_{4}^{2-}$. Dissolution of $\mathrm{SO}_{2}$ within cloud water is calculated according to Henry's law. In the aqueous phase, the oxidation of $\mathrm{SO}_{2}$ by hydrogen peroxide $\left(\mathrm{H}_{2} \mathrm{O}_{2}\right)$ and ozone $\left(\mathrm{O}_{3}\right)$ are considered. The oxidant concentrations are prescribed as three dimensional monthly mean fields from calculations of the MOZART chemical transport model (Horowitz et al., 2003). Gas phase produced sulfate is allowed to condensate onto pre-existing particles or to nucleate to new particles, calculated by the aerosol microphysical module M7. In-cloud produced sulfate is distributed to the available pre-existing accumulation mode and coarse mode aerosol particles according to their respective number concentration. The deposition processes, i.e. wet deposition, dry deposition, and sedimentation, are calculated online in dependence of aerosol size and composition.

The radiation module calculates the aerosol optical properties explicitly from the prognosed size distribution, compo-

cursor gases in the years 2000 and 1750 - prescribed data-sets for AeroCom, Atmos. Chem. Phys. Discuss., submitted, 2006. 
sition and mixing state which are then passed to the radiation scheme of ECHAM5. Only the effects of the aerosols on the solar part of the spectrum are considered.

For this study the ECHAM5-HAM model has been extended by a technique to mark $\mathrm{SO}_{2}$ and $\mathrm{SO}_{4}^{2-}$ attributable to DMS. This allows to isolate the fraction of DMS-derived $\mathrm{SO}_{2}$ and $\mathrm{SO}_{4}^{2-}$. Such a quantification facilitates to assess the importance of aerosols of DMS origin. Additionally, the knowledge of the contribution of DMS to $\mathrm{SO}_{4}^{2-}$ enables us to use $\mathrm{SO}_{4}^{2-}$ concentration measurements at sites with a relatively high contribution of DMS to $\mathrm{SO}_{4}^{2-}$ for an evaluation of the atmospheric DMS cycle in the model.

\subsection{Model setup}

The ocean and the atmosphere models are coupled with the OASIS coupler (Valcke et al., 2003) with a coupling time step of one day. The ocean model MPI-OM passes the sea surface temperature and sea ice variables to the atmosphere through OASIS. The atmosphere model ECHAM5-HAM uses these boundary conditions for one coupling timestep and transfers the surface forcing fields through OASIS back to the ocean model. Required surface forcing fields are heat, freshwater and momentum fluxes, downward solar radiation and the $10 \mathrm{~m}$ wind speed. Additionally the DMS flux to the atmosphere calculated in HAMOCC5 is passed to the atmosphere model and the dust deposition calculated in the HAM model is passed to HAMOCC5 through OASIS. The model does not employ flux adjustments.

In order to initialize the coupled atmosphere-ocean AOGCM, the uncoupled ocean model was integrated over thousand years to reach quasi-equilibrium state. From there on the coupled AOGCM was integrated with fixed external forcing to reach quasi-equilibrium state. From these initial conditions the simulation is started and integrated for 15 years. The results presented here are averaged over the last 10 years.

\section{Results}

\subsection{Ocean}

A detailed description of the simulated ocean and biochemical mean state of MPI-OM/HAMOCC5 is given in Wetzel (2004). On average, the simulated global net primary production is $24 \mathrm{GtC} \mathrm{yr}^{-1}$. The export production, defined as the part of the net primary production that is transported out of the euphotic zone, amounts to $5 \mathrm{GtC} \mathrm{yr}^{-1}$, which is on the low end of model and observational estimates (Oschlies, 2002). The global annual averaged export of calcium carbonate is $0.27 \mathrm{GtC} \mathrm{yr}^{-1}$, which leads to a rain ratio (the ratio of calcium carbonate to organic carbon in export production) of 0.06 on average. This ratio lies within current estimates
(Sarmiento et al., 2002) and leads to a realistic alkalinity distribution.

Wetzel (2004) shows that the model is able to reproduce chlorophyll distribution from the SeaWIFS satellite, except for the coastal regions, where shelf processes and riverine input of nutrients are not captured by the global model. Additionally, the model tends to simulate higher chlorophyll concentrations in the Southern Ocean and in the subtropical gyres than derived from satellite observations. Wetzel (2004) concludes that this might be predominantly a result of the modeled ocean dynamic with too strong vertical mixing in the Southern Ocean and a too weak downwelling in the subtropical gyres.

A novel feature of the coupled model used in this study, is that dust deposition fields are calculated interactively in the atmospheric model and passed once per day to the ocean, instead of prescribing the dust deposition from climatological mean fields. This provides the means to apply this model for longterm climate change simulations including the effects of varying dust depositions, caused by climate change, on the marine biogeochemistry and on the DMS sea surface concentration. Assuming an iron content in dust of $3.5 \%$ we simulated an annual global mean iron deposition flux of $666 \mathrm{Gmol}(\mathrm{Fe}) \mathrm{yr}^{-1}$, whereby $204 \mathrm{Gmol}(\mathrm{Fe}) \mathrm{yr}^{-1}$ are deposited to the ocean surface. The iron deposition onto the ocean surface lies within the range used in other global marine biogeochemistry studies (Fung et al., 2000: $118 \mathrm{Gmol}(\mathrm{Fe}) \mathrm{yr}^{-1}$, Aumont et al., 2003: $149.7 \mathrm{Gmol}(\mathrm{Fe}) \mathrm{yr}^{-1}$, Archer and Johnson, 2000: 131.7$\left.487.4 \mathrm{Gmol}(\mathrm{Fe}) \mathrm{yr}^{-1}\right)$. The wide range given in the global iron deposition rates highlights the uncertainties in the iron content of dust particles, as in the magnitude and the size variation of the dust emission and deposition in the atmosphere.

In the following section we will focus on the simulated DMS sea surface concentrations and compare our results to measurements as well as to a recently developed DMS algorithm by Simó and Dachs (2002).

\subsubsection{DMS in the ocean}

HAMOCC5 simulates a global total DMS production of $351 \mathrm{Tg}(\mathrm{S}) \mathrm{yr}^{-1}$. The loss of DMS in the ocean proceeds mainly via the consumption by bacteria $\left(294 \mathrm{Tg}(\mathrm{S}) \mathrm{yr}^{-1}\right)$. The DMS flux into the atmosphere $\left(28 \mathrm{Tg}\left(\mathrm{S}_{)} \mathrm{yr}^{-1}\right)\right.$ accounts for $8 \%$ of the global DMS removal in the ocean, the photooxidation $\left(31 \mathrm{Tg}(\mathrm{S}) \mathrm{yr}^{-1}\right)$ for $9 \%$.

The relative rates of the decay processes are not well constrained through measurements, in particular on a global scale. Archer et al. (2002) found a DMS flux equivalent to $10 \%$ of the DMS production in a six day Lagrangian experiment conducted in the northern North Sea. DMS removal by bacterial consumption accounted for the majority of the DMS removal (62-82\% for surface levels and $98 \%$ for subsurface levels). Similar findings are reported for the Eastern 
(a)

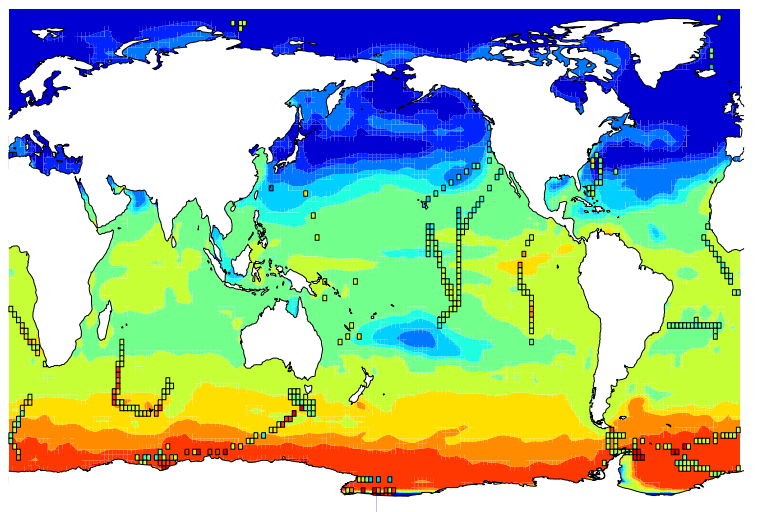

$\begin{array}{lllllllllll}0 & 0.1 & 0.2 & 0.5 & 0.7 & 1 & 2 & 5 & 7 & 10 & 20\end{array}$

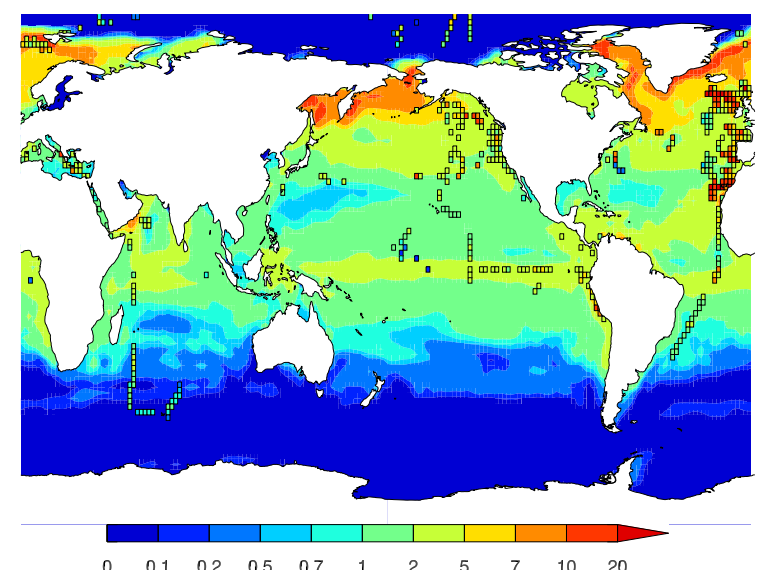

(b)

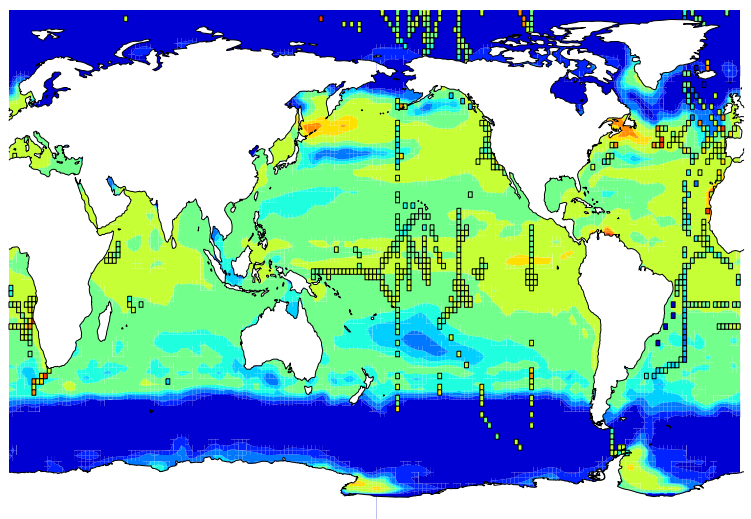

$\begin{array}{lllllllllll}0 & 0.1 & 0.2 & 0.5 & 0.7 & 1 & 2 & 5 & 7 & 10 & 20\end{array}$

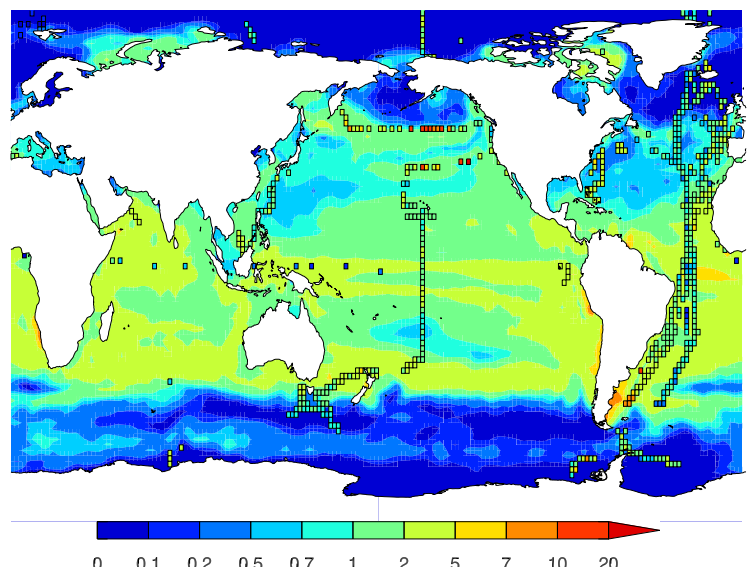

Fig. 1. Modeled seasonal mean DMS sea surface concentration. (a) Mean for December, January, February; (b) Mean for March, April, May; (c) Mean for June, July, August; (d) Mean for September, November, December. Overlayed grid boxes are ocean data points given in the Kettle and Andreae (2000) database (data points where the ocean depth is below $300 \mathrm{~m}$ are excluded) gridded onto the model grid. Units are $\mathrm{nmoll}^{-1}$.

Tropical Pacific where measurements show a 3 to 430 times faster removal of DMS by biological consumption than by the DMS flux into the atmosphere (Kiene and Bates, 1990) and for the North East Pacific where biological consumption accounted for $67 \%$ of the total DMS consumption and the DMS flux accounted for only a small fraction $(1 \%)$ of the DMS loss (Bates et al., 1994). The simulated annual mean decay rates are in accordance with these findings. However, for an evaluation of the simulated production and decay processes more measurements are needed.

The simulated seasonal mean sea surface concentrations of DMS are shown in Fig. 1. The predicted DMS concentrations show moderate values, generally exceeding $1-$ $2 \mathrm{nmoll}^{-1}$, in the biological active upwelling zones like the equatorial Pacific Ocean, or in the upwellings off Peru and Angola throughout the year. The subtropical gyres in both hemispheres show low DMS sea surface concentrations. The polar oceans (North Pacific, North Atlantic and Southern Ocean) feature high DMS concentrations with values up to $20 \mathrm{nmoll}^{-1}$ in the Southern Ocean in the respective summer seasons.
The predicted annual global mean DMS sea surface concentration lies with $1.8 \mathrm{nmol}^{-1}$ within the range of annual mean concentrations from DMS climatologies (Kettle et al., 1999: $2.1 \mathrm{nmoll}^{-1}$, Kettle and Andreae, 2000: $2.0 \mathrm{nmoll}^{-1}$, Anderson et al., 2001: $2.6 \mathrm{nmol}^{-1}$, Aumont et al., 2002: $1.7 \mathrm{nmoll}^{-1}$, Simó and Dachs, 2002: $2.3 \mathrm{nmoll}^{-1}$, Chu et al., 2003: $1.5 \mathrm{nmol}^{-1}$, Belviso et al., 2004b: $1.6 \mathrm{nmol}^{-1}$; global numbers taken from Belviso et al., 2004a).

Figure 2a compares the percentage frequency distribution of the DMS sea surface concentration with the percentage frequency distribution of measurements given in the Kettle and Andreae (2000) database. The data points of the Kettle and Andreae (2000) database were distributed onto the model grid on a monthly mean basis and only corresponding model values are taken into account. Data points where the ocean depth is less than $300 \mathrm{~m}$ are excluded. Therefore, many of the high DMS sea surface concentrations measured in shelf regions are not considered. Values with DMS sea surface concentrations higher than $20 \mathrm{nmoll}^{-1}$ are not shown. The measurements show 32 data points with DMS sea surface concentrations higher than $20 \mathrm{nmol}^{-1}$, for the simulation we find 25 values. 

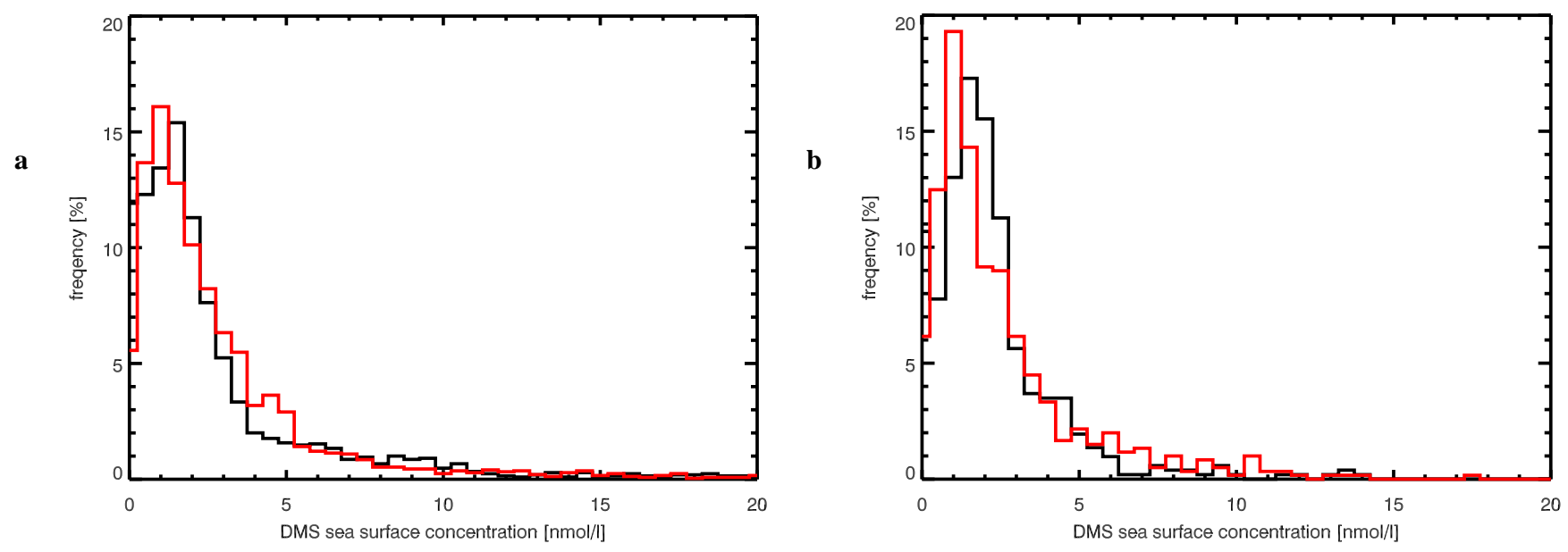

Fig. 2. Percentage frequency distribution of simulated and measured DMS sea surface concentrations. (a) Measurements from the Kettle and Andreae (2000) database. (b) Measurements obtained from http://saga.pmel.noaa.gov/dms/, excluding the measurements of the Kettle and Andreae (2000) database. The Measurements are gridded onto the model grid. The simulated distribution is shown in black, the measured distribution in red. Data points with an ocean depth greater than $300 \mathrm{~m}$ and DMS sea surface concentrations greater than $20 \mathrm{nmol} 1^{-1}$ are excluded.

The percentage frequency distributions show highest values for low DMS sea surface concentrations, whereby the observations show a maximum for 1.0 to $1.5 \mathrm{nmoll}^{-1}$ and the simulation for 1.5 to $2.0 \mathrm{nmol}^{-1}$. Moderate DMS sea surface concentrations $\left(2.5\right.$ to $\left.5.5 \mathrm{nmol}^{-1}\right)$ are less frequent in the simulation than in the observations. For higher DMS sea surface concentrations ( $10 \mathrm{nmol} 1^{-1}$ and higher) both the model and the observations show a very low frequency with less than $1 \%$. Overall the model tends to underestimate DMS sea surface concentrations in the moderate DMS regimes, but it captures the high frequency of low DMS sea surface concentrations and the low frequency of the high DMS sea surface concentrations.

Since the Kettle and Andreae (2000) database was used for the optimization of the model parameters the comparison might be misleading. For an independent evaluation we compare the simulation with the updated version of the Kettle and Andreae (2000) database (Global Surface Seawater Dimethylsulfide (DMS) Database, available at http: //saga.pmel.noaa.gov/dms/) which has been extended by additional 12866 DMS sea surface measurements by 10 different measurement campaigns. Compared to the Kettle and Andreae (2000) database the data coverage of the additional measurements is sparse. By gridding the measurement data points onto the model grid, only 572 grid boxes are assigned to an annual mean DMS sea surface concentration value, whereby the Kettle and Andreae (2000) data points cover 2301 grid boxes. The percentage frequency distribution is displayed in Fig. 2b. Similar to the Kettle and Andreae (2000) database the observations show the highest frequency for 1.0 to $1.5 \mathrm{nmoll}^{-1}$ and the simulation for 1.5 to $2.0 \mathrm{nmoll}^{-1}$. The agreement for moderate DMS sea surface concentrations ( 2.5 to $5.5 \mathrm{nmol}^{-1}$ ) is reasonably well, whereby higher DMS sea surface concentrations are less frequent in the simulation.

Monthly latitudinal profiles of the model results, the Kettle and Andreae (2000) database data and the DMS sea surface climatology from Kettle and Andreae (2000) are compared in Fig. 3. Only data points where the ocean depth is above $300 \mathrm{~m}$ are used. As DMS is a product of marine biological activity, the DMS sea surface concentration has large seasonal variations. This is especially pronounced in the high latitudes where DMS concentrations peak in the Southern Hemisphere in December and in the Northern Hemisphere in June. The amplitude of the seasonal variation is lower in the model than in the Kettle and Andreae (2000) climatology. However, the climatology is based only on a few data points in this region. Around the equator the modeled DMS sea surface concentrations stay almost constant with $2-3 \mathrm{nmol}^{-1}$ throughout the year. This value is confirmed by measurements in these latitudes and present as well in the Kettle and Andreae (2000) climatology. Overall the model simulates the observed DMS sea surface concentrations reasonably well.

\subsubsection{DMS concentration predicted from mixed layer depth and chlorophyll $\alpha$}

Simó and Dachs (2002) developed a two equation algorithm to predict DMS sea surface concentrations using chlorophyll $\alpha$ surface concentrations (CHL) and the mixed layer depth (MLD). Our model setup allows to apply the proposed algorithm to the simulated MLD and sea surface chlorophyll $\alpha$ concentration. We compare the resulting DMS sea surface concentration to the one given in Simó and Dachs (2002) using climatological input fields and to the one simulated within the marine biogeochemistry model. The DMS 

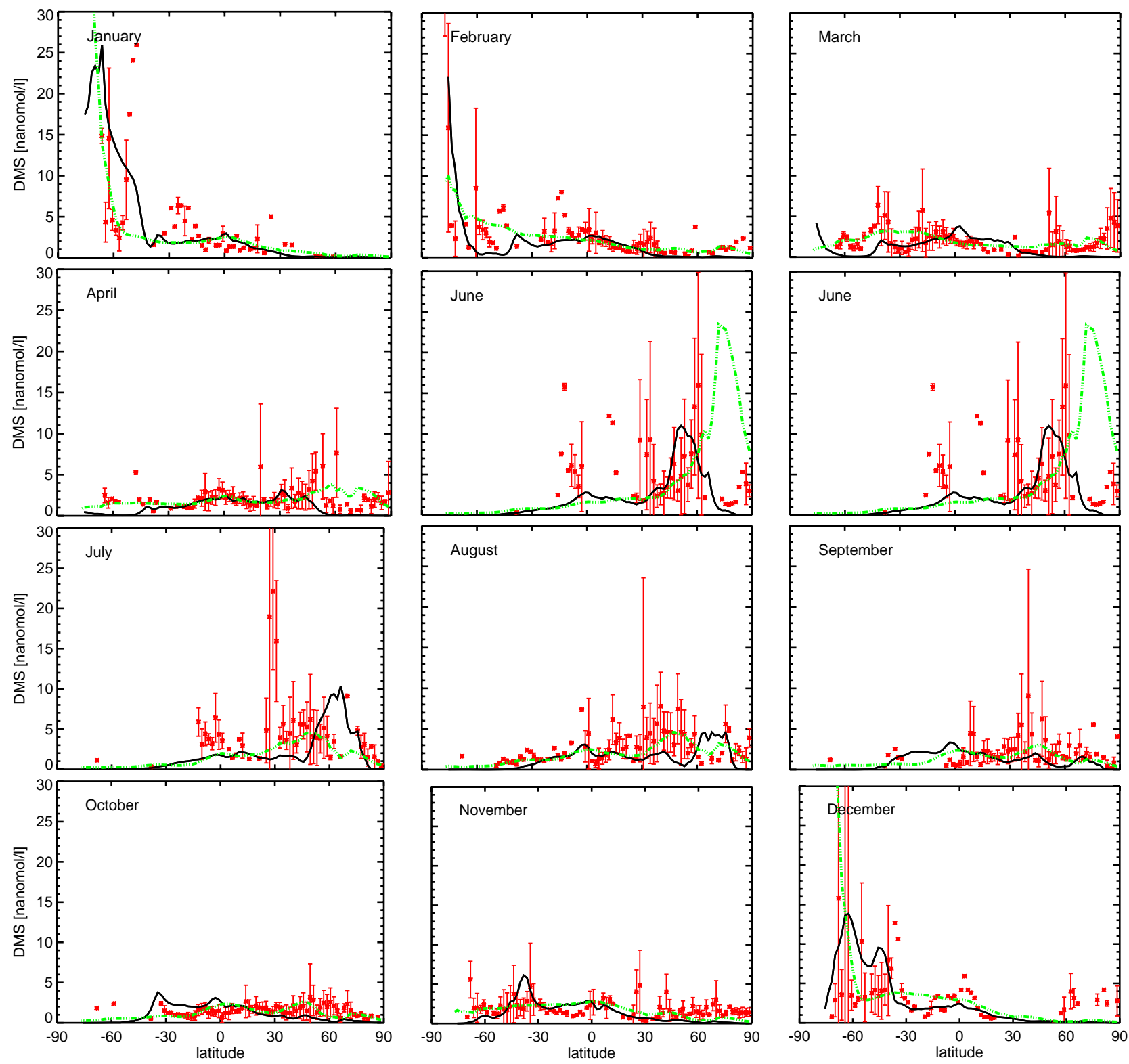

Fig. 3. Zonally averaged profiles of DMS sea surface concentrations for all months. The black line represents the zonal average of the modeled DMS sea surface concentration, the green line the zonal average of the Kettle and Andreae (2000) DMS sea surface climatology. The red symbols represent the zonally averaged ocean data points given in the Kettle and Andreae (2000) database (data points where the ocean depth is below $300 \mathrm{~m}$ are excluded) gridded onto the model grid. Where more than one ocean grid box is present, the standard deviation is given by the red vertical line. Units are nmoll ${ }^{-1}$.

algorithm is formulated by Simó and Dachs (2002) as follows:

$$
\begin{array}{ll}
\mathrm{DMS}=-\ln (\mathrm{MLD})+5.7, & \mathrm{CHL} / \mathrm{MLD}<0.02 \\
\mathrm{DMS}=55.8(\mathrm{CHL} / \mathrm{MLD})+0.6, & \mathrm{CHL} / \mathrm{MLD} \geq 0.02
\end{array}
$$

The units of MLD are $\mathrm{m}$, of CHL are $\mathrm{mg} \mathrm{m}^{-3}$, and of DMS sea surface concentrations are $n m o l 1^{-1}$. The algorithm is based on the assumption of Simó and Pedrós-Alió (1999) that vertical mixing plays a major role in controlling the production of DMS in the sea surface layers. They found that
DMS is quantitatively related to the ratio of chlorophyll $\alpha$ and MLD, leading to high DMS concentrations not only associated with high chlorophyll $\alpha$ concentrations but also with moderate chlorophyll $\alpha$ concentrations and a concurrent shallow MLD. They explained this relation with the fact that a shallow mixing tends to favor phytoplankton blooms of taxa with a high DMSP cell content. Simó and Dachs (2002) derived global monthly DMS sea surface concentrations using a global monthly climatology for the MLD (Samuel and Cox' GFDL Global Oceanographic Data Set 
Atlas, available at http://dss.ucar.edu/datasets/ds279.0/) and chlorophyll $\alpha$ concentration from SeaWiFS averaged over the period September 1997 to November 2000. The MLD is equally defined by the density criterion as in our simulation (depth where $\Delta \sigma_{\mathrm{t}}=0.125$ relative to the surface). We applied the proposed relationship using the simulated MLD and chlorophyll $\alpha$ concentration. In about $80 \%$ of the total ocean surface, the ratio CHL/MLD is $<0.02$ and Eq. (10) applies. If the MLD exceeds $298 \mathrm{~m}$, Eq. (10) results in a prediction of negative DMS values. This is the case for $9 \%$ of the total ocean surface. We excluded these values. A monthly mean MLD deeper than $298 \mathrm{~m}$ is simulated in the winter months in the North Atlantic and in the Southern Ocean. This is consistent with observations and also present in the Samuel and Cox MLD climatology, whereby here only $2 \%$ of the ocean surface shows a monthly mean MLD deeper than $298 \mathrm{~m}$. Figure 4 shows the resulting zonal annual mean DMS sea surface concentrations compared to the concentration obtained from our simulation, the concentration from Simó and Dachs (2002) using climatological input fields and the concentration from the Kettle and Andreae (2000) climatology.

The DMS sea surface concentration derived from the Simó and Dachs (2002) algorithm with simulated MLD and chlorophyll $\alpha$ concentration is comparable to the one derived by Simó and Dachs (2002) using a MLD climatology and chlorophyll $\alpha$ concentrations from SeaWiFS. Discrepancies occur in the high latitudes where during the summer months high chlorophyll $\alpha$ concentrations persist and predominantly Eq. (11) applies. The DMS sea surface concentration resulting from the simulated MLD and chlorophyll $\alpha$ concentration is higher in the southern high latitudes and slightly lower in the northern high latitudes. The lower values in the northern high latitudes are caused by a simulated deeper mixed layer depth compared to the Samuel and Cox climatology. For the southern high latitudes high simulated chlorophyll $\alpha$ concentrations lead to high DMS sea surface concentrations. The simulated chlorophyll $\alpha$ concentrations are slightly higher than the satellite estimates and probably overestimated by the model (Wetzel, 2004). However, particularly in the high latitudes the climatological fields comprise large uncertainties which are caused by a sparse data coverage for the MLD and by frequent cloud contamination for the satellite derived chlorophyll $\alpha$ concentration.

The simulated DMS sea surface concentration using the DMS formulation introduced in the marine biogeochemistry model HAMOCC5 results in distinct different zonal annual mean concentration variations compared to DMS sea surface concentration derived with the Simó and Dachs (2002) algorithm. Particularly in the Northern Hemisphere our simulation results in significantly lower DMS sea surface concentrations which are in agreement with the measurements given in the Kettle and Andreae (2000) database and present as well in the DMS sea surface climatology from Kettle and Andreae (2000). Both show a minimum in the DMS sea surface concentration around $30^{\circ} \mathrm{N}$ which is not captured with the Simó

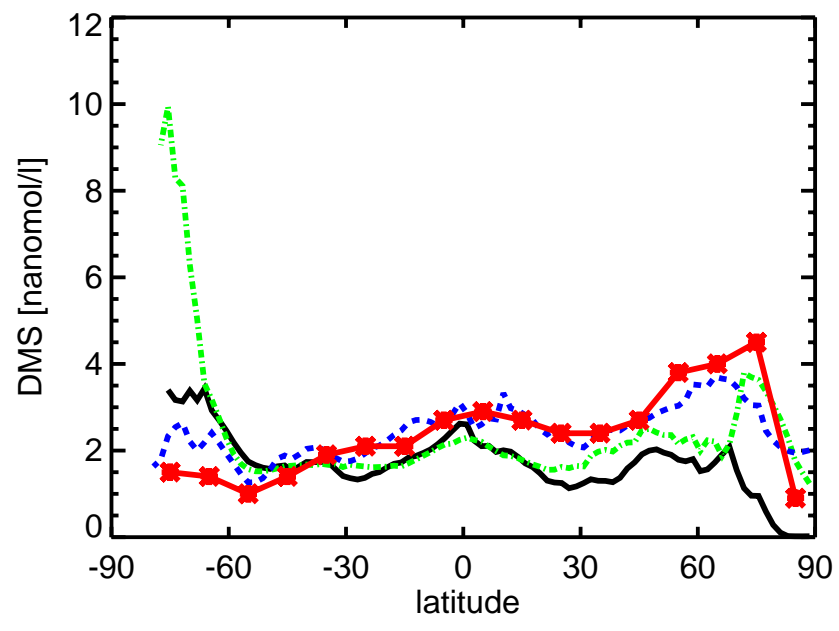

Fig. 4. Zonal annual means of sea surface DMS for the Simó and Dachs (2002) algorithm using the simulated MLD and chlorophyll $\alpha$ concentration (dashed blue line), resulting concentrations from the simulation using the marine biogeochemistry model HAMOCC5 (black line), annual mean DMS sea surface concentration averaged over $10^{\circ}$ latitudinal bands given in Simó and Dachs (2002) using climatological MLD and chlorophyll $\alpha$ concentration from SeaWiFS (red stars) and for the Kettle and Andreae (2000) climatology (dotted green line). Units are $n m o l 1^{-1}$.

and Dachs (2002) algorithm. Discrepancies are highest in the northern high latitudes. In the late summer, with moderate chlorophyll $\alpha$ concentrations in the northern high latitudes, the Simó and Dachs (2002) algorithm predominately relies on the MLD only. This results in a broadening of the summer maximum leading to high annual mean DMS sea surface concentration in this region. The Kettle and Andreae (2000) climatology shows as the Simó and Dachs (2002) algorithm high DMS sea surface concentrations in the northern high latitudes. The high values in the climatology are probably caused by the inclusion of DMS measurements from the North Sea region. We excluded these datapoints for the optimization of our DMS formulation. The remaining measurements mainly show DMS sea surface concentrations around $1-2 \mathrm{nmol}^{-1}$ (see Fig. 3) which is consistent with our simulation.

\subsection{DMS sea-air exchange}

As described in Sect. 2.2.1 we use the DMS sea-air exchange parameterization after Wanninkhof (1992) utilizing the $10 \mathrm{~m}$ wind speed and the sea surface temperature provided by the atmospheric model part ECHAM5 to calculate the DMS flux interactively in the model. The resulting global annual mean DMS flux is $28 \mathrm{Tg}(\mathrm{S}) \mathrm{yr}^{-1}$. Estimates of the global DMS flux differ widely depending mainly on the used DMS sea surface climatology, sea-air exchange parameterization, and wind speed data, ranging from $16 \mathrm{Tg}(\mathrm{S}) \mathrm{yr}^{-1}$ up to $54 \mathrm{Tg}(\mathrm{S}) \mathrm{yr}^{-1}$ (see e.g. Kettle and Andreae, 2000 for 
Table 3. Sulfur budget: global, Northern Hemisphere and Southern Hemisphere. The lifetime is calculated as the ratio of the column burden to the sum of all sources.

\begin{tabular}{|c|c|c|c|}
\hline & $\mathrm{SH}$ & $\mathrm{NH}$ & Global \\
\hline \multicolumn{4}{|l|}{ DMS } \\
\hline $\begin{array}{l}\text { Source }\left(\operatorname{Tg}(S) \mathrm{yr}^{-1}\right) \text { : } \\
\text { total: }\end{array}$ & 17.8 & 9.8 & 27.6 \\
\hline Sinks $\left(\operatorname{Tg}(\mathrm{S}) \mathrm{yr}^{-1}\right)$ : & & & \\
\hline oxidation with $\mathrm{OH}$ & 15.8 & 7.5 & 23.3 \\
\hline oxidation with $\mathrm{NO}_{3}$ & 1.8 & 2.4 & 4.2 \\
\hline burden $(\operatorname{Tg}(S))$ : & 0.056 & 0.021 & 0.077 \\
\hline lifetime (d): & 1.15 & 0.78 & 1.02 \\
\hline \multicolumn{4}{|l|}{$\mathrm{SO}_{2}$} \\
\hline $\begin{array}{l}\text { Source }\left(\operatorname{Tg}(\mathrm{S}) \mathrm{yr}^{-1}\right) \text { : } \\
\text { total (Emission + DMS oxidation) }\end{array}$ & 25.9 & 69.3 & 94.2 \\
\hline $\begin{array}{l}\text { Sinks }\left(\mathrm{Tg}(\mathrm{S}) \mathrm{yr}^{-1}\right) \text { : } \\
\text { oxidation }\end{array}$ & 21.6 & 51.7 & 73.3 \\
\hline dry deposition & 2.9 & 14.3 & 17.3 \\
\hline wet deposition & 1.4 & 2.2 & 3.6 \\
\hline burden $(\operatorname{Tg}(S))$ : & 0.19 & 0.41 & 0.60 \\
\hline lifetime (d) : & 2.7 & 2.2 & 2.4 \\
\hline \multicolumn{4}{|l|}{$\mathrm{SO}_{4}^{2-}$} \\
\hline \multicolumn{4}{|l|}{ Source $\left(\operatorname{Tg}(\mathrm{S}) \mathrm{yr}^{-1}\right)$ : } \\
\hline \multicolumn{4}{|l|}{ Sinks $\left(\operatorname{Tg}(\mathrm{S}) \mathrm{yr}^{-1}\right]$ : } \\
\hline $\begin{array}{l}\text { condensation } \\
\text { nucleation }\end{array}$ & $\begin{array}{l}8.7 \\
0.05\end{array}$ & $\begin{array}{l}18.2 \\
0.06\end{array}$ & $\begin{array}{l}26.8 \\
0.11\end{array}$ \\
\hline wet deposition & 0.02 & 0.02 & 0.04 \\
\hline dry deposition & 0.002 & 0.004 & 0.006 \\
\hline burden $(\operatorname{Tg}(S))$ : & 0.0003 & 0.0004 & 0.0007 \\
\hline lifetime (d): & 0.014 & 0.008 & 0.010 \\
\hline \multicolumn{4}{|l|}{$\mathrm{SO}_{4}^{2-}$} \\
\hline $\begin{array}{l}\text { Source }\left(\mathrm{Tg}(\mathrm{S}) \mathrm{yr}^{-1}\right) \text { : } \\
\text { total }\left(\text { Emission }+\mathrm{SO}_{2} \text { in cloud oxidation }+\right. \\
\text { condensation }+ \text { nucleation })\end{array}$ & 24.4 & 53.9 & 78.4 \\
\hline $\begin{array}{l}\text { Sinks }\left(\operatorname{Tg}(\mathrm{S}) \mathrm{yr}^{-1}\right) \text { : } \\
\text { dry deposition }\end{array}$ & 0.6 & 1.8 & 2.5 \\
\hline wet deposition & 23.3 & 50.8 & 74.1 \\
\hline sedimentation & 0.56 & 1.29 & 1.85 \\
\hline burden $(\operatorname{Tg}(S))$ : & 0.24 & 0.49 & 0.73 \\
\hline lifetime $(d)$ : & 3.64 & 3.32 & 3.42 \\
\hline
\end{tabular}

a review). Kettle and Andreae (2000) calculated a global DMS flux between 27 and $32 \mathrm{Tg}(\mathrm{S}) \mathrm{yr}^{-1}$ with their DMS sea surface climatology applying the same sea-air exchange parameterization (Wanninkhof, 1992) and four different combinations of data sets for the wind speed and sea surface temperature. Our simulated global annual mean DMS flux is in agreement with their findings. Figure 5 displays the global distribution of the annual mean DMS flux into the atmosphere. The distribution of the DMS flux is closely related to the DMS sea surface distribution (c.f. Fig. 1). High DMS fluxes persist in regions with high DMS sea surface concentrations, such as the equatorial Pacific and Atlantic Ocean and in high wind speed regions, e.g. the broad band with el-
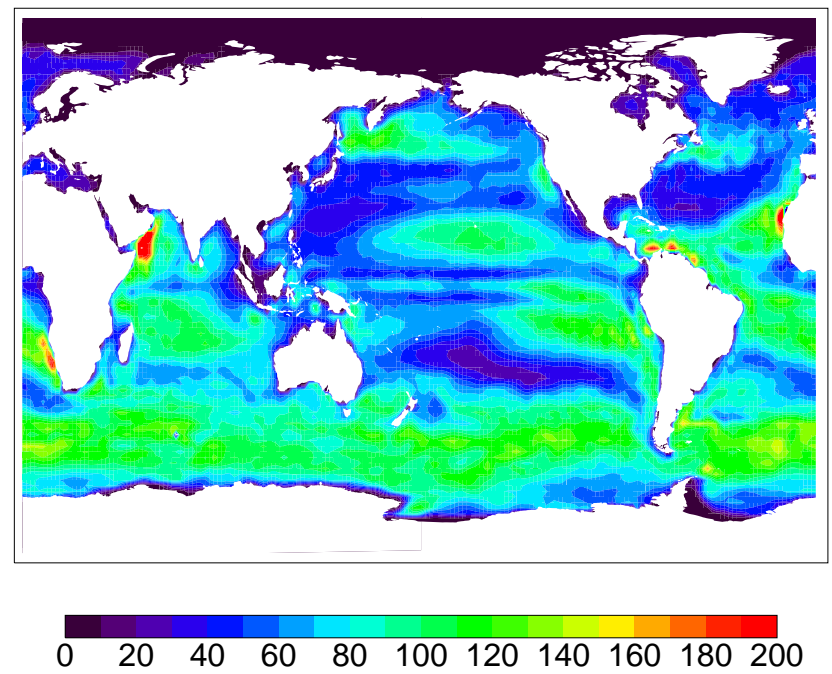

Fig. 5. Annual mean DMS flux into the atmosphere. Units are $\mathrm{mg}(\mathrm{S}) \mathrm{m}^{-2} \mathrm{yr}^{-1}$

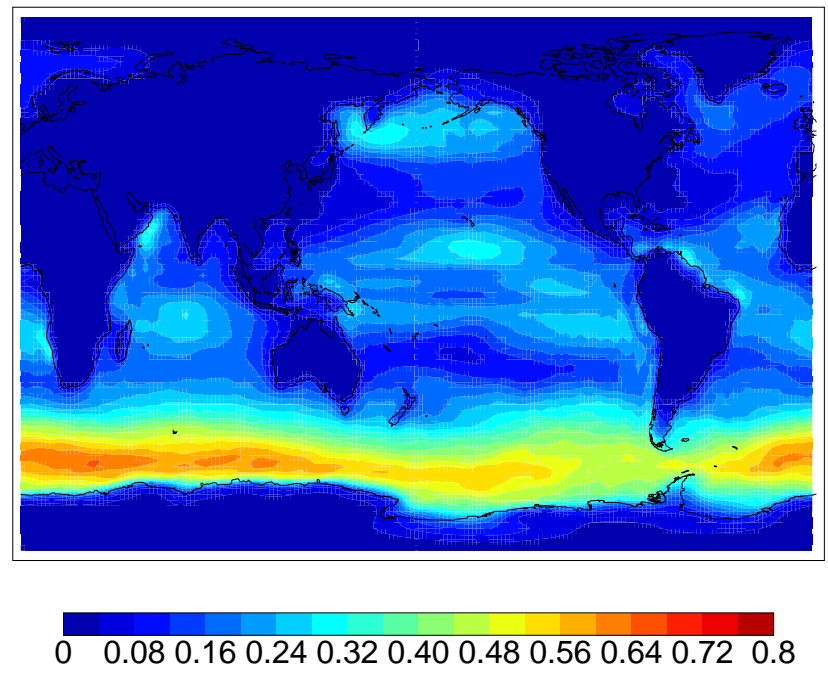

Fig. 6. Annual mean DMS column burden. Units $\operatorname{are~} \mathrm{mg}(\mathrm{S}) \mathrm{m}^{-2}$.

evated DMS emissions in the Southern Ocean between $40^{\circ}$ and $60^{\circ} \mathrm{S}$.

\subsection{The atmospheric sulfur cycle}

\subsubsection{Global budgets}

Table 3 summarizes the characteristics of the global DMS and sulfur budgets. Globally, the DMS emission flux is $28 \mathrm{Tg}(\mathrm{S}) \mathrm{yr}^{-1}$. The highest emissions are simulated in the Southern Hemisphere $\left(17.6 \mathrm{Tg}(\mathrm{S}) \mathrm{yr}^{-1}\right)$. Compared to the total $\mathrm{SO}_{2}$ source resulting from $\mathrm{SO}_{2}$ emissions from anthropogenic sources, wildfires and volcanic eruptions as prescribed from the AEROCOM emission scenario and $\mathrm{SO}_{2}$ resulting from DMS oxidation, DMS accounts for $30 \%$ of 


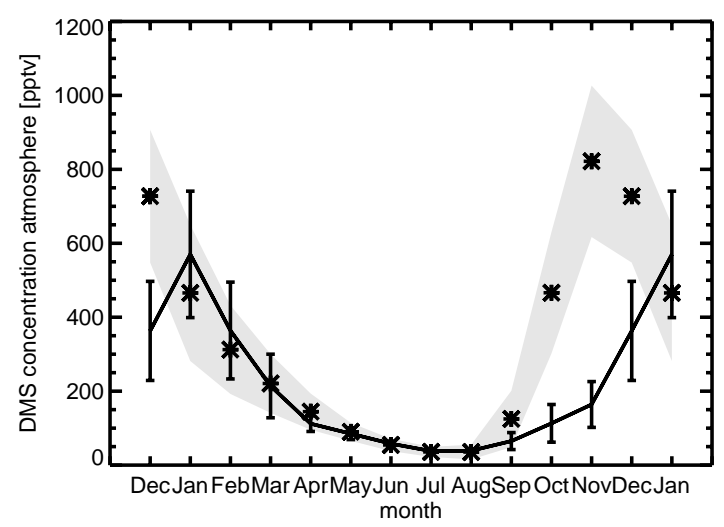

(b)

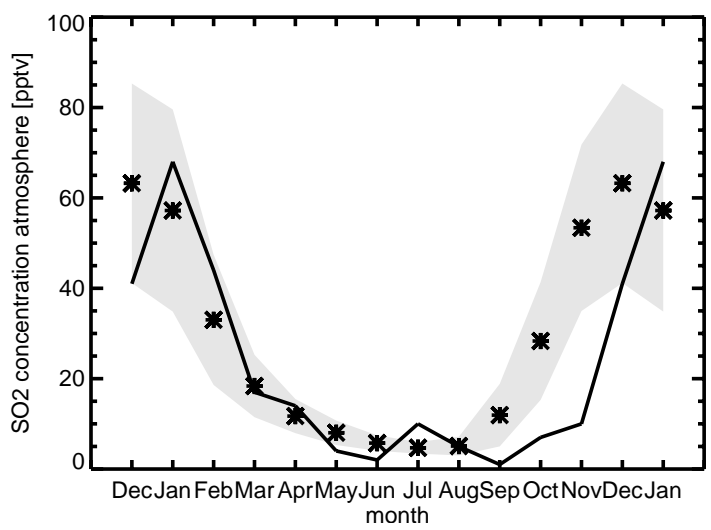

Fig. 7. (a) Atmospheric DMS at Amsterdam Island, measurements and standard deviation after (Sciare et al., 2000). (b) Atmospheric SO at Amsterdam Island, the measurements are reported by Putaud et al. (1992). The line represents the measurements, stars the model results. The grey shading indicates the monthly mean simulated standard deviation. Units are pptv.

the total sulfur source $(14 \%$ in the Northern Hemisphere and $67 \%$ in the Southern Hemisphere). Globally, $84 \%$ of the DMS is removed via oxidation by $\mathrm{OH}$ radicals. This ratio is close to the one reported in other studies using similar DMS reaction mechanisms (Berglen et al., 2004: 73\%, Chin et al., 2000: 88\%, Pham et al., 1995: 86\%). Oxidation by $\mathrm{NO}_{3}$ is more important in the Northern Hemisphere $(8.7 \%)$ than in the Southern Hemisphere $(6.5 \%)$. The annual global mean DMS burden is with $0.08 \mathrm{Tg}(\mathrm{S})$ in agreement with other studies (Chin et al., 2000: $0.07 \mathrm{Tg}(\mathrm{S})$, Koch et al., 1999: $0.06 \operatorname{Tg}(\mathrm{S})$, Pham et al., 1995: $0.05 \operatorname{Tg}(\mathrm{S}))$ as is the lifetime with 1.0 days (Chin et al., 2000: 2.0 days, Koch et al., 1999: 1.9 days, Pham et al., 1995: 0.9 days). The chemical conversion is the major sink for $\mathrm{SO}_{2}(78 \%)$. The dry deposition accounts for only $18 \%$ of the total removal. This is low compared to other studies, as already pointed out by Stier et al. (2005). The serial resistance dry deposition scheme used here results in significantly lower $\mathrm{SO}_{2}$ dry deposition fluxes compared to other studies (Ganzeveld et al., 1998). The low dry deposition sink results in a high yield of $\mathrm{SO}_{4}^{2-}$ from the chemical conversion of $\mathrm{SO}_{2}$ into $\mathrm{SO}_{4}^{2-} \cdot \mathrm{SO}_{4}^{2-}$ is mainly wet deposited (95\%). Dry deposition accounts for $3 \%$ and sedimentation for $2 \%$ of the total $\mathrm{SO}_{4}^{2-}$ removal.

\subsubsection{DMS in the atmosphere}

The annual global distribution of the DMS burden is displayed in Fig. 6. Highest burdens persist in the Southern Hemisphere, in particular around $60^{\circ} \mathrm{S}$. This agrees with the high DMS flux simulated in this region. Additionally, DMS experiences a longer lifetime in the Southern Hemisphere compared to the Northern Hemisphere (1.15 days compared to 0.78 days, respectively). In the industrialized Northern Hemisphere, high $\mathrm{NO}_{3}$ levels ensure a steady oxidation of DMS even during nighttime when $\mathrm{OH}$ concentrations are zero. About $88 \%$ of DMS emitted in the Southern Hemisphere is oxidized by $\mathrm{OH}$ and $12 \%$ by $\mathrm{NO}_{3}$. In the Northern
Hemisphere, $77 \%$ is oxidized by $\mathrm{OH}$ and $23 \%$ by $\mathrm{NO}_{3}$. In the Southern Hemisphere, the limited removal of DMS via $\mathrm{NO}_{3}$ due to the low $\mathrm{NO}_{3}$ concentrations leads to an accumulation of DMS and a higher atmospheric DMS burden compared to the Northern Hemisphere $(0.056 \mathrm{Tg}(\mathrm{S})$ compared to $0.021 \mathrm{Tg}(\mathrm{S})$, respectively).

In Fig. 7a simulated and observed seasonal variations of atmospheric DMS concentrations are compared at Amsterdam Island in the Southern Ocean (Sciare et al., 2000). Atmospheric DMS mixing ratios were measured on a daily basis from August 1990 to December 1999. Shown are monthly mean values. The simulated seasonal variation is in agreement with the observations. However, the summer maximum is overestimated and shifted by two months in the model. Highest concentrations are simulated in November (822 pptv), whereas the observations show a maximum in January (557 pptv).

Figure $7 \mathrm{~b}$ shows the simulated $\mathrm{SO}_{2}$ concentration at Amsterdam Island compared to measurements reported by Putaud et al. (1992). The measurements were taken for the period March 1989 to January 1991 . The $\mathrm{SO}_{2}$ concentrations show a similar seasonal variation as the DMS concentrations, both in the simulation and in the measurements. The amplitude of the seasonal cycle which is defined by the ratio $\mathrm{R}=$ (average concentration for December, January and February)/(average concentration for June, July and August), is 8 for the measured as well as for the simulated $\mathrm{SO}_{2}$ concentrations. The amplitude of the seasonal atmospheric DMS cycle is simulated equal to 9 and measured equal to 8 and is comparable to that of $\mathrm{SO}_{2}$. The seasonal variation of the atmospheric DMS concentration at Amsterdam Island is largely driven by variations in the DMS sea surface concentration. The seasonal amplitude of the sea surface DMS is simulated equal to 9 and fits exactly the simulated seasonal cycle for DMS in the atmosphere (data not shown). 

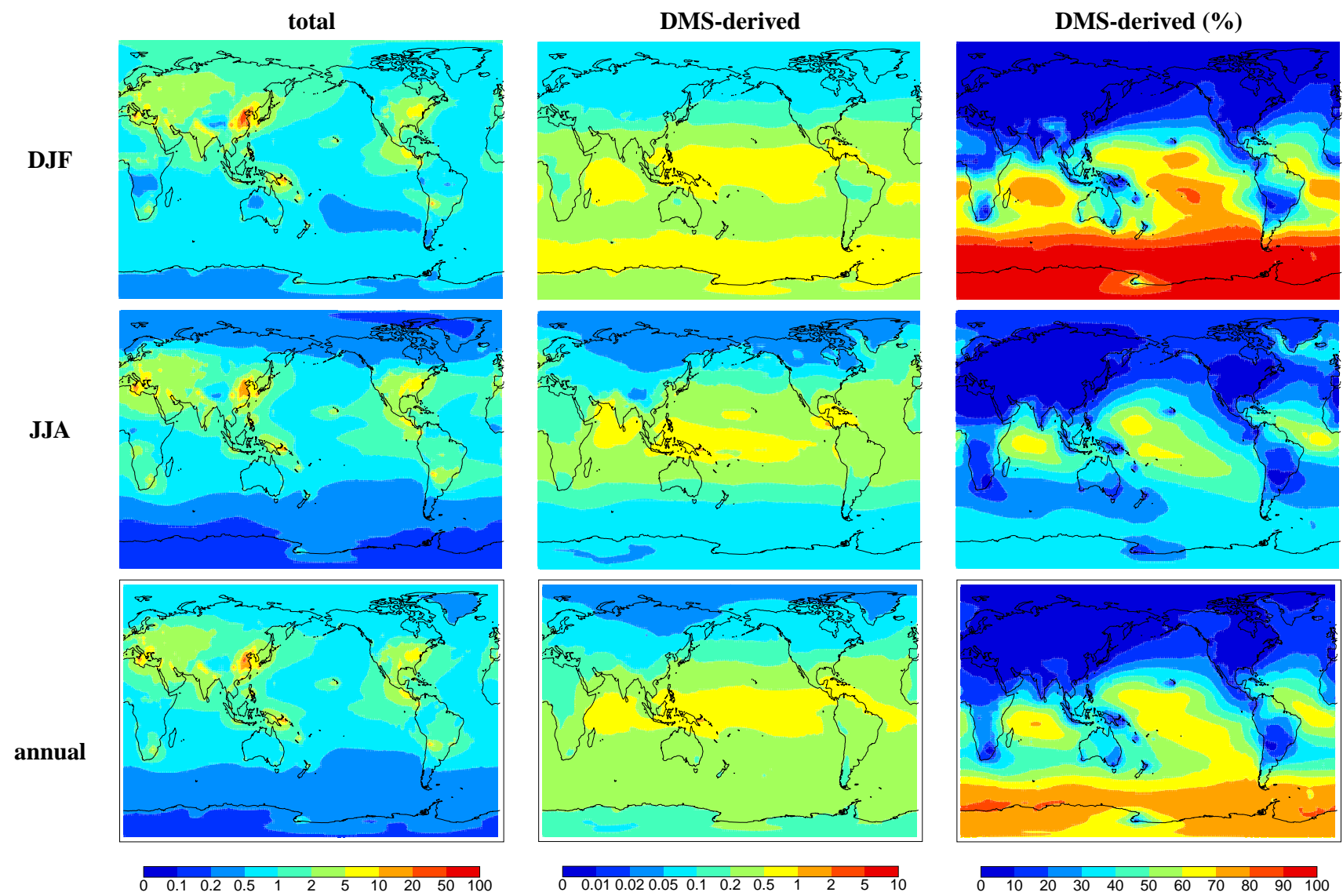

Fig. 8. Mean column burdens of $\mathrm{SO}_{2}$ averaged for December, January and February (DJF) and June, July and August (JJA) and annual mean values resulting from all sources (total), resulting solely from DMS (DMS-derived) and percentage of $\mathrm{SO}_{2}$ attributable to DMS (DMS-derived $(\%)$, respectively. Units are $\mathrm{mg}(\mathrm{S}) \mathrm{m}^{-2}$ and $\%$, respectively.

Table 4. Annual mean column burdens of DMS, $\mathrm{SO}_{2}, \mathrm{SO}_{4}^{2-}$ resulting from all sulfur sources (total) in (Tg(S)) and resulting only from DMS in $(\%)$.

\begin{tabular}{lrrrrrrrrr}
\hline & \multicolumn{3}{c}{ annual mean } & \multicolumn{3}{c}{ December/January/ } & \multicolumn{3}{c}{ June/July/August } \\
& global & $\mathrm{NH}$ & $\mathrm{SH}$ & global & $\mathrm{NH}$ & $\mathrm{SH}$ & global & $\mathrm{NH}$ & $\mathrm{SH}$ \\
\hline $\mathrm{DMS}(\mathrm{Tg}(\mathrm{S}))$ & 0.077 & 0.021 & 0.056 & 0.151 & 0.013 & 0.137 & 0.048 & 0.032 & 0.016 \\
$\mathrm{SO}_{2}$ total $(\mathrm{Tg}(\mathrm{S}))$ & 0.604 & 0.414 & 0.190 & 0.642 & 0.440 & 0.202 & 0.592 & 0.400 & 0.192 \\
$\%$ of $\mathrm{SO}_{2}$ from DMS & 24.7 & 15.7 & 44.2 & 28.8 & 15.0 & 58.9 & 21.0 & 15.8 & 31.25 \\
$\mathrm{SO}_{4}^{2-}$ total $(\mathrm{Tg}(\mathrm{S}))$ & 0.733 & 0.493 & 0.240 & 0.674 & 0.363 & 0.311 & 0.813 & 0.617 & 0.195 \\
$\%$ of $\mathrm{SO}_{4}^{2-}$ from DMS & 26.7 & 17.8 & 45.0 & 37.2 & 20.7 & 56.6 & 21.3 & 17.5 & 33.3 \\
\hline
\end{tabular}

\subsubsection{DMS contribution to $\mathrm{SO}_{2}$ and $\mathrm{SO}_{4}^{2-}$ column burdens}

In order to quantify the importance of DMS-derived $\mathrm{SO}_{2}$ and $\mathrm{SO}_{4}^{2-}$, we simulated the contribution of DMS-derived $\mathrm{SO}_{2}$ and $\mathrm{SO}_{4}^{2-}$ to the total $\mathrm{SO}_{2}$ and $\mathrm{SO}_{4}^{2-}$ concentration in the atmosphere. Additionally, this allows to utilize $\mathrm{SO}_{4}^{2-}$ concentration measurements in regions with a high DMS contribution for an evaluation of the DMS cycle.
$\mathrm{SO}_{2}$ column burden

The spatial distribution of the total $\mathrm{SO}_{2}$ column burden, the $\mathrm{SO}_{2}$ column burden resulting from DMS and the relative contribution of the DMS-derived $\mathrm{SO}_{2}$ to the total $\mathrm{SO}_{2}$ column burden are displayed in Fig. 8. Shown are annual averages, averages for June, July and August and for December, January and February. The same is shown for the 

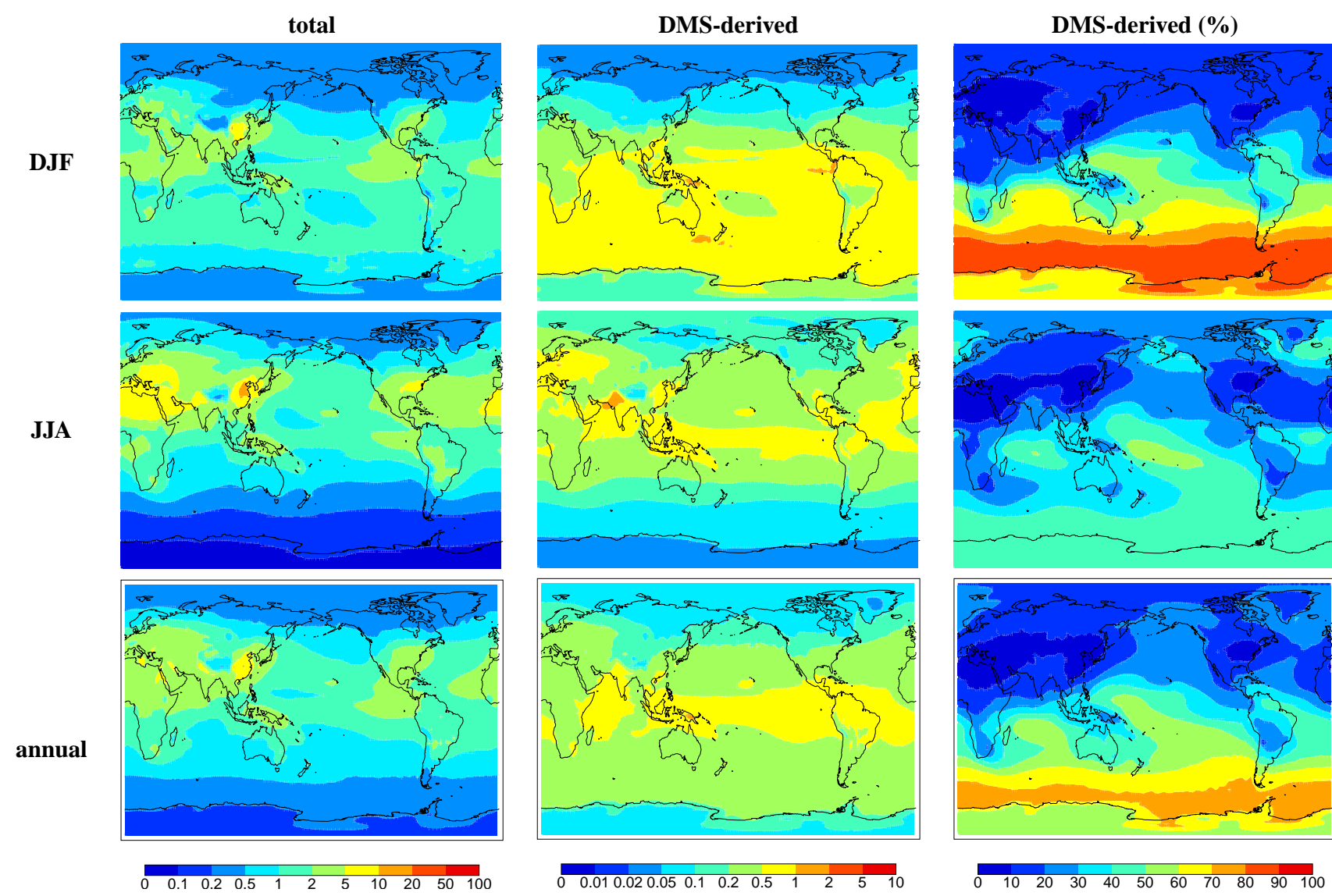

Fig. 9. Mean column burdens of $\mathrm{SO}_{4}^{2-}$ averaged for December, January and February (DJF) and June, July and August (JJA) and annual mean values resulting from all sources (total), resulting solely from DMS (DMS-derived) and percentage of $\mathrm{SO}_{4}^{2-}$ attributable to DMS (DMS-derived $(\%)$, respectively. Units are $\mathrm{mg}(\mathrm{S}) \mathrm{m}^{-2}$ and \%, respectively.

$\mathrm{SO}_{4}^{2-}$ column burden in Fig. 9. The respective global mean column burdens are summarized in Table 4 .

The global distribution of $\mathrm{SO}_{2}$ column burdens resulting from all sources reflects the dominant anthropogenic sulfur sources in the Northern Hemisphere, most pronounced over the industrialized areas of Europe, North America and China. The $\mathrm{SO}_{2}$ column burden resulting from DMS emission alone highlights the strong seasonal variation of DMS in the atmosphere. The highest column burdens persist in the Southern Hemisphere for December, January and February with values up to $1 \mathrm{mg}(\mathrm{S}) \mathrm{m}^{-2}$ in high latitudes. The maximum in the Northern Hemisphere for June, July and August is less pronounced. In the equatorial regions, the $\mathrm{SO}_{2}$ column burden attributable to DMS stays almost constant throughout the year. The simulated high DMS sea surface concentration here causes a steady emission of DMS into the atmosphere and therefore a high load of $\mathrm{SO}_{2}$ derived from DMS integrated over the atmospheric column. The relative contribution of DMS-derived $\mathrm{SO}_{2}$ to the total $\mathrm{SO}_{2}$ shows clearly the overwhelming role of DMS in the Southern Hemisphere during the biological active season. In December, January and February the contribution is up to $90 \%$.
The simulated global annual burden of $\mathrm{SO}_{2}$ is $0.60 \mathrm{Tg}(\mathrm{S})$, $25 \%$ of which can be attributed to DMS. Compared to the DMS contribution to the total sulfur emissions source, which is globally $30 \%$, the contribution of DMS to the $\mathrm{SO}_{2}$ column burden is reduced. The contribution is greatest in the Southern Hemisphere (44\%). The anthropogenic sources are dominant in the Northern Hemisphere. DMS accounts for $16 \%$ of the total $\mathrm{SO}_{2}$ column burden on the annual mean in the Northern Hemisphere. Even in the summer months (June, July and August), when maximum DMS sea surface concentrations are simulated in the Northern Hemisphere, the contribution of DMS to the total $\mathrm{SO}_{2}$ column burden is greatest in the Southern Hemisphere (32\% compared to $17 \%$ in the Northern Hemisphere).

\section{$\mathrm{SO}_{4}^{2-}$ column burden}

The global distribution of the $\mathrm{SO}_{4}^{2-}$ column burden resulting from all sources shows highest burdens close to the main sources and the sources of its precursor $\mathrm{SO}_{2}$ in the Northern Hemisphere (Fig. 9). Significant export to low emission regions, for example the Middle East, North Africa, the North 


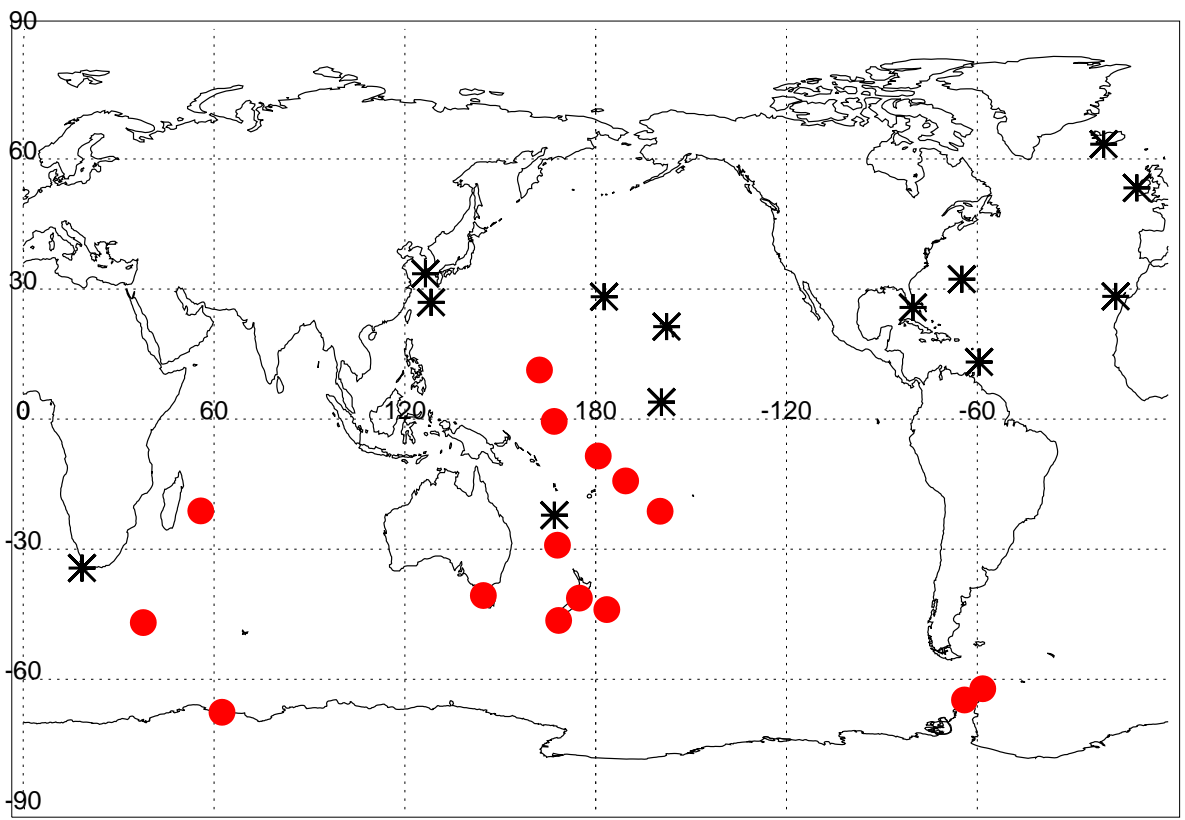

Fig. 10. Location of the measurement sites included in the University of Miami network. Red points indicate stations with a simulated annual mean DMS contribution to $\mathrm{SO}_{4}^{2-}$ at the surface higher than $50 \%$.

Pacific and the North Atlantic, occurs throughout the year. The $\mathrm{SO}_{4}^{2-}$ column burden resulting from DMS emissions alone shows almost the same distribution as the $\mathrm{SO}_{2}$ column burden resulting from DMS. A high burden persists in the Southern Hemisphere in the summer season. The export of $\mathrm{SO}_{4}^{2-}$ into low emission regions causes a slight southward shift of the areas significantly influenced by DMS emissions. While for the $\mathrm{SO}_{2}$ burden a contribution of DMS of 60 to $70 \%$ for December, January and February is simulated in the equatorial regions of the Pacific and Atlantic, the contribution for $\mathrm{SO}_{4}^{2-}$ lies only between 40 to $50 \%$.

The global annually averaged column burden of $\mathrm{SO}_{4}^{2-}$ is $0.73 \mathrm{Tg}(\mathrm{S})$ with a DMS contribution of $27 \%$ globally. The greatest contribution occurs in December, January and February with up to $37 \%$ globally and $57 \%$ in the Southern Hemisphere. The DMS contribution to the $\mathrm{SO}_{4}^{2-}$ burden lies within the same range as the DMS contribution to the $\mathrm{SO}_{2}$ column burden. This is caused by the simulated strong chemical conversion rate of $\mathrm{SO}_{2}$ to $\mathrm{SO}_{4}^{2-}$.

\subsubsection{DMS-derived $\mathrm{SO}_{4}^{2-}$ in the atmosphere}

The global distribution of the fraction of the $\mathrm{SO}_{4}^{2-}$ burden attributable to DMS shows the dominant role of DMS as $\mathrm{SO}_{4}^{2-}$ precursor in the Southern Hemisphere, in particular at high latitudes (Fig. 9). A comparison of the simulated $\mathrm{SO}_{4}^{2-}$ concentrations with measurements in these remote regions therefore gives an indication of the representation of the DMS cycle in the model simulation. Several measurement networks include $\mathrm{SO}_{4}^{2-}$ surface concentration measurements.
We choose the multi-annual measurements from the University of Miami network (D. Savoie, personal communication), as this network includes mainly measurements from remote sites. These measurements have been conducted mainly on islands or at coastal stations. The number of measurement years varies with site. The measurement locations are displayed in Fig. 10. Red points indicate stations with a simulated annual contribution of DMS to $\mathrm{SO}_{4}^{2-}$ of more than $50 \%$ within the lowest model layer. These stations are mainly located in the Southern Hemisphere.

Figure 11 shows the scatter of the measured and simulated $\mathrm{SO}_{4}^{2-}$ surface concentration. Shown are monthly, annual, boreal winter (December, January and February), and boreal summer (June, July and August) mean values. In addition, Table 5 lists the annual mean values for all measurement locations together with the relative contribution of DMS to $\mathrm{SO}_{4}^{2-}$ in the lowest model layer. Out of a total of 320 monthly mean samples, $213(67 \%)$ agree within a factor of 2 with the measurements. The model overestimates the $\mathrm{SO}_{4}^{2-}$ surface concentrations especially for low concentrations. The lowest values reported coincide with locations where anthropogenic influences are low and where therefore the DMS contribution to $\mathrm{SO}_{4}^{2-}$ generally exceeds $50 \%$. On the annual mean, 15 stations show a contribution of DMS greater than $50 \%$. 9 of these stations lie within a factor of 2 within the measurement values. At the remaining stations the concentrations are all overpredicted by the model. This becomes exceedingly evident for the Southern Hemisphere summer season (mean over December, January and February) where the DMS sea surface concentration and the DMS 

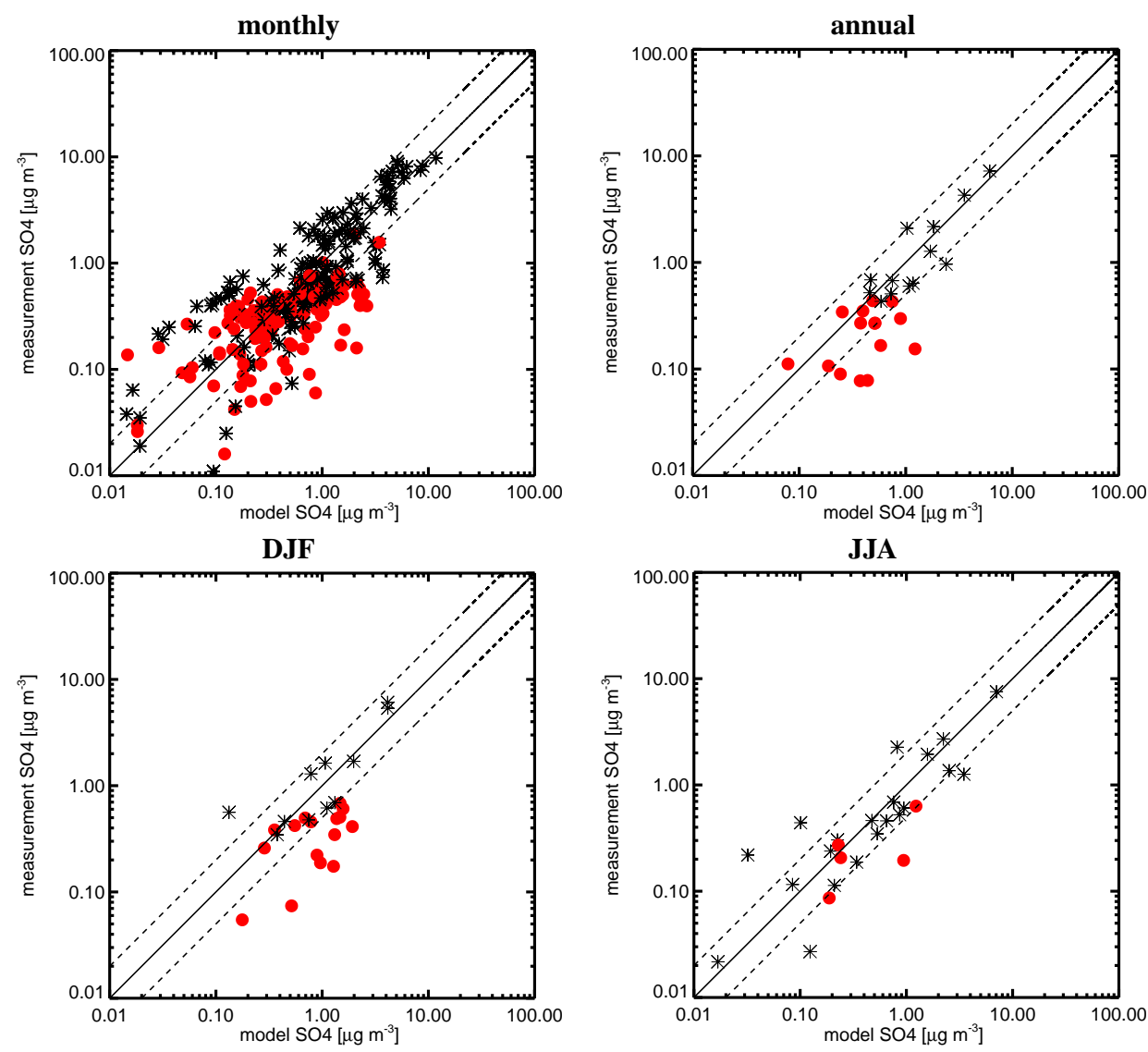

Fig. 11. Scatter plot of measured and simulated surface aerosol mass concentration of $\mathrm{SO}_{4}^{2-}$. Measurements are from the University of Miami network. (a) Monthly mean, (b) annual mean, (c) mean for December, January and February, (d) mean for June, July and August. Red symbols indicate a contribution of DMS to $\mathrm{SO}_{4}^{2-}$ higher than $50 \%$. The solid line indicates the 1:1 ratio, the dashed lines the 1:2 and 2:1 ratios. Units are $\mu \mathrm{g}(\mathrm{S}) \mathrm{m}^{-3}$.

emission are high. DMS contributions higher than 50\% appear in 17 stations. For 12 stations with a contribution higher than $50 \%$, the simulated values are a factor of 2 higher than the measured values. During the winter months (mean over June, July and August) DMS contributions higher than $50 \%$ exist for only 5 locations, 2 of which show higher simulated than measured values. In summary, for remote measurement stations the simulated $\mathrm{SO}_{4}^{2-}$ surface concentrations are in agreement with the reported measurement values. Discrepancies from the observed values are highest for locations with a high DMS contribution, in particular in the summer season of the Southern Hemisphere. Here the model overpredicts the averaged observed concentrations by a factor of 2.3.

This overestimation may be caused by too high DMS emissions in these regions which are either due to too high DMS sea surface concentrations or too high sea-air exchange rates. The simulated DMS sea surface concentrations in summer in the Southern High Latitudes are very high compared to other regions of the ocean. Measurements reported from these regions confirm these high concentrations in the sea surface layers. The model tends to slightly overestimate these high values. The differences lie thereby in the range of the standard deviation and cannot solely explain the too high simulated atmospheric $\mathrm{SO}_{4}^{2-}$ surface concentrations. The sea-air exchange rate parameterization used (Wanninkhof, 1992) leads to the highest flux compared to other existing sea-air exchange rate parameterizations (e.g. Nightingale et al., 2000; Liss and Merlivat, 1986). Differences in the DMS flux can be up to a factor of 2 (e.g. Kettle and Andreae, 2000; Boucher et al., 2003). Despite too high simulated DMS emissions, one possible reason for the overestimated $\mathrm{SO}_{4}^{2-}$ surface concentration might be a missing reaction mechanism of DMS in the atmosphere preventing the formation of $\mathrm{SO}_{4}^{2-}$. Several studies highlight the importance of the reaction of DMS with bromine oxide $(\mathrm{BrO})$ radicals leading to the formation of DMSO (e.g. von Glasow and Crutzen, 2004; Boucher et al., 2003). This reaction mechanism is not included in our study. DMSO reacts with $\mathrm{OH}$ in the atmosphere, whereas the reaction products are uncertain. It has been postulated that dimethyl sulphone $\left(\mathrm{DMSO}_{2}\right)$ is the main oxidation product leading to the formation of 
Table 5. List of measurements sites from the University of Miami Network used in Fig. 11.

\begin{tabular}{|c|c|c|c|c|c|}
\hline Location & Longitude & Latitude & $\begin{array}{r}\text { Model } \\
\text { annual mean } \\
\left(\mu \mathrm{g} \mathrm{m}^{-3}\right)\end{array}$ & $\begin{array}{r}\text { Measurements } \\
\text { annual mean } \\
\left(\mu \mathrm{g} \mathrm{m}^{-3}\right)\end{array}$ & $\begin{array}{r}\text { DMS contribution } \\
\text { annual mean } \\
(\%)\end{array}$ \\
\hline Chatham Island - New Zealand & -176.5 & -43.9 & 0.52 & 0.27 & 59 \\
\hline Cape Point - South Africa & 18.5 & -34.3 & 1.08 & 0.60 & 37 \\
\hline Cape Grim - Tasmania & 144.7 & -40.7 & 0.89 & 0.30 & 51 \\
\hline Iinverargill - New Zealand & 168.4 & -46.4 & 0.49 & 0.44 & 60 \\
\hline Marsh - King George Island & -58.3 & -62.2 & 0.38 & 0.27 & 52 \\
\hline Marion Island & 37.8 & -46.9 & 0.44 & 0.08 & 61 \\
\hline Mawson - Antarctica & 62.5 & -67.6 & 0.08 & 0.11 & 73 \\
\hline Palmer Station - Antarctica & -64.1 & -64.8 & 0.24 & 0.09 & 63 \\
\hline Reunion Island & 55.8 & -21.2 & 0.40 & 0.35 & 54 \\
\hline Wellingtin - New Zealand & 174.9 & -41.3 & 0.75 & 0.43 & 52 \\
\hline Yate - New Caledonia & 167.0 & -22.1 & 0.59 & 0.43 & 45 \\
\hline Funafuti - Tuvalu & -179.2 & -8.5 & 0.58 & 0.17 & 60 \\
\hline Nauru & 166.9 & -0.5 & 1.22 & 0.15 & 58 \\
\hline Norfolk Island & 168.0 & -29.1 & 0.51 & 0.27 & 55 \\
\hline Rarotonga - Cook Islands & -159.8 & -21.2 & 0.19 & 0.11 & 65 \\
\hline American Samoa & -170.6 & -14.2 & 0.25 & 0.34 & 64 \\
\hline Midway Island & -177.4 & 28.2 & 0.46 & 0.52 & 33 \\
\hline Oahu Hawaii & -157.7 & 21.3 & 0.73 & 0.51 & 33 \\
\hline Cheju - Korea & 126.5 & 33.5 & 6.14 & 7.21 & 6 \\
\hline Hedo Okinawa - Japan & 128.2 & 26.9 & 3.55 & 4.28 & 15 \\
\hline Fanning Island & -159.3 & 3.9 & 1.17 & 0.64 & 48 \\
\hline Enewetak Atoll & 162.3 & 11.3 & 0.37 & 0.08 & 55 \\
\hline Barbados & -59.4 & 13.2 & 0.75 & 0.67 & 38 \\
\hline Izana Tenerife & -16.5 & 29.3 & 2.40 & 0.96 & 22 \\
\hline Bermuda & -64.9 & 32.3 & 1.03 & 2.09 & 22 \\
\hline Heimaey Iceland & -20.3 & 63.4 & 0.47 & 0.69 & 26 \\
\hline Mace Head - Ireland & -9.9 & 53.3 & 1.70 & 1.27 & 22 \\
\hline Miami & -80.2 & 25.8 & 1.82 & 2.17 & 18 \\
\hline
\end{tabular}

methyl sulfinic acid (MSIA) and methyl sulfonic acid (MSA) (Yin et al., 1990). A 1-D model study for marine boundary layer conditions (von Glasow and Crutzen, 2004) shows that the inclusion of halogen chemistry increases the DMS destruction by about $25 \%$ in summer and $100 \%$ in winter time. The $\mathrm{SO}_{2}$ yield from the oxidation of DMS is simulated lower when halogen chemistry is included. However, the lack of $\mathrm{BrO}$ measurements in the atmosphere makes a global assessment of the importance of the $\mathrm{BrO}$ oxidation difficult.

\section{Summary and conclusions}

The production of marine dimethylsulfide (DMS) and its fate in the atmosphere are simulated in a global coupled atmosphere-ocean circulation model. The processes for marine DMS production and decay are included in the representation of plankton dynamics in the marine biogeochemistry model HAMOCC5 embedded in a global ocean general circulation model (MPI-OM). The atmospheric model
ECHAM5 is extended by the microphysical aerosol model HAM.

The simulated DMS sea surface concentrations generally match the observed concentrations. The seasonal variation with its high DMS sea surface concentration in the high latitudes in the summer hemispheres is captured by the model. The global annual mean DMS sea surface concentration of $1.8 \mathrm{nmol}^{-1}$ lies within the range of DMS sea surface climatologies (e.g. Belviso et al., 2004a).

We apply our simulated mixed layer depth (MLD) and chlorophyll $\alpha$ concentration to the Simó and Dachs (2002) algorithm, to calculate DMS sea surface concentrations solely from this two quantities. The resulting zonal mean DMS sea surface distribution is comparable to the one derived by Simó and Dachs (2002) using climatological MLD fields and chlorophyll $\alpha$ concentrations from SeaWiFS. However, compared to the DMS sea surface concentration simulated with the biogeochemical model the Simó and Dachs (2002) algorithm results in distinct different DMS sea surface distributions. This is most pronounced in the Northern Hemisphere, 
with simulated values lower than the ones predicted from the Simó and Dachs (2002) algorithm.

The treatment of DMS in a coupled atmosphere-ocean model including a microphysical aerosol scheme and an atmospheric sulfur model allows to gain additional insight into the DMS representation in the model by a comparison with atmospheric DMS related measurements. The simulated DMS flux into the atmosphere is $28 \mathrm{Tg}(\mathrm{S}) \mathrm{yr}^{-1}$ which is in the range of current estimates (e.g. Kettle and Andreae, 2000). The resulting column integrated burden of DMS in the atmosphere is $0.08 \mathrm{Tg}(\mathrm{S})$ and the lifetime is 1.0 days. DMS contributes $30 \%$ to the total sulfur source considered in the model (sulfur emissions from fossil- and bio- fuel use, wildfires and volcanoes and sulfur from DMS oxidation). The contribution of $\mathrm{SO}_{2}$ derived from oxidation of DMS by $\mathrm{OH}$ and $\mathrm{NO}_{3}$ to the total $\mathrm{SO}_{2}$ column burden is $25 \%$. $\mathrm{SO}_{2}$ is oxidized by $\mathrm{OH}$ in the gas phase and by $\mathrm{H}_{2} \mathrm{O}_{2}$ and $\mathrm{O}_{3}$ in the aqueous phase to form $\mathrm{SO}_{4}^{2-} .27 \%$ of the produced $\mathrm{SO}_{4}^{2-}$ can be attributed to DMS oxidation. The contribution is highest in the biologically active season in remote regions of the Southern Ocean with values up to $90 \%$.

The comparison of $\mathrm{SO}_{4}^{2-}$ measurements and simulated $\mathrm{SO}_{4}^{2-}$ concentrations at remote sites where the contribution of DMS to $\mathrm{SO}_{4}^{2-}$ is generally high shows an overestimation of the $\mathrm{SO}_{4}^{2-}$ surface concentrations by the model, most pronounced in the biologically active season. Possible explanations are an overestimation of the DMS sea surface concentration, a too high sea-air exchange rate or a missing reaction mechanism of DMS in the atmosphere. The simulated DMS sea surface concentrations are generally in agreement with the observations. A direct validation of the DMS flux is not possible because it cannot yet be measured directly. A missing reaction of DMS in the atmosphere model is the reaction with $\mathrm{BrO}$. It has been shown by several investigators that this reaction is important in remote regions (e.g. von Glasow and Crutzen, 2004; Boucher et al., 2003). However, the concentration of $\mathrm{BrO}$ in the atmosphere is not well known which makes a global assessment not feasible.

Future work will be to include the next step of the proposed DMS-climate feedback, i.e. the connection between aerosols and the cloud microphysics. The prognostic treatment of aerosol size distribution, composition and mixing state in the ECHAM5-HAM model provides the basis for such a microphysical coupling of the aerosol and the cloud scheme with an explicit simulation of cloud droplet and ice crystal number concentrations. For an assessment of the DMS-cloud link, it is important to consider sea salt and its role as CCN. Sea-salt emissions are high in regions with high DMS emissions and are also influenced by climate change.

The generally good agreement between model and measurements indicates that the DMS cycle in the model represents the processes governing DMS sea surface concentrations, DMS emissions and resulting atmospheric concentrations reasonably well. However, the lack of measurements of the consumption and production processes of DMS in the ocean hampers the full evaluation of the DMS formulation as a predictive tool for DMS. Nevertheless, the DMS formulation applied in a coupled ocean-atmosphere model is a step forwards in providing a model system to assess marine biosphere-climate feedbacks.

Acknowledgements. We wish to thank J. Prospero and D. Savoie (University of Miami) for providing the compilation of the multi-annual surface observations and J. Kettle for the maps of biogeochemical provinces. Many thanks to S. Legutke for the help with the OASIS coupler. We would also like to acknowledge the support of the German DEKLIM project funded by the German Ministry for Education and Research (BMBF) and the support of the International Max Planck Research School for Earth System Modelling. The simulations were done on the HLRE the High Performance Computing System for Earth System Research at the German Climate Computing Center (DKRZ).

Edited by: T. W. Lyons

\section{References}

Anderson, T. R., Spall, S. A., Yool, A., Cipollini, P., Challenor, P. G., and Fasham, M. J. R.: Global fields of sea surface Dimethylsulfide predicted from chlorophyll, nutrients and light, J. Mar. Systems, 30, 1-20, 2001.

Andreae, M. O. and Crutzen, P. J.: Atmospheric aerosols: Biogeochemical sources and role in atmospheric chemistry, Science, 276, 1052-1058, 1997.

Andreae, M. O., Elbert, W., and Demora, S. J.: Biogenic sulfur emissions and aerosols over the tropical South-Atlantic. 3: Atmospheric Dimethylsulfide, aerosols and cloud condensation nuclei, J. Geophys. Res., 100, 11 335-11 356, 1995.

Andreae, M. O., Elbert, W., Cai, Y., Andreae, T. W., and Gras, J.: Non-sea-salt sulfate, methanesulfonate, and nitrate aerosol concentrations and size distributions at Cape Grim, Tasmania, J. Geophys. Res., 104, 21 695-21 706, 1999.

Andres, R. J. and Kasgnoc, A. D.: A time-averaged inventory of subaerial volcanic sulfur emissions, J. Geophys. Res., 103, 25 251-25 261, 1998.

Archer, D. E. and Johnson, K.: A model of the iron cycle in the ocean, Global Biogeochem. Cycles, 14, 269-279, 2000.

Archer, S. D., Smith, G. C., Nightingale, P. D., Widdicombe, C. E., Tarran, G. A., Rees, A. P., and Burkill, P. H.: Dynamics of particulate Dimethylsulphoniopropionate during a lagrangian experiment in the northern North Sea, Deep-Sea Res., 49, 2979-2999, 2002.

Aumont, O., Belviso, S., and Monfray, P.: Dimethylsulfoniopropionate (DMSP) and Dimethylsulfide (DMS) sea surface distributions simulated from a global three-dimensional ocean carbon cycle model, J. Geophys. Res., 107, doi:10.1029/1999JC000111, 2002.

Aumont, O., Maier-Reimer, E., Blain, S., and Monfray, P.: An ecosystem model of the global ocean including $\mathrm{Fe}, \mathrm{Si}, \mathrm{P}$ colimitations, Global Biogeochem. Cycles, 17, doi:10.1029/2001GB001745, 2003. 
Ayers, G. P. and Gillett, R. W.: DMS and its oxidation products in the remote marine atmosphere: Implications for climate and atmospheric chemistry, J. Sea Res., 43, 275-286, 2000.

Bates, T. S., Calhoun, J. A., and Quinn, P. K.: Variations in the methanesulfonate to sulfate molar ratio in submicrometer marine aerosol-particles over the South-Pacific ocean, J. Geophys. Res., 97, 9859-9865, 1992.

Bates, T. S., Kiene, R. P., Wolfe, G. V., Matrai, P. A., Chavez, F. P., Buck, K. R., Blomquist, B. W., and Cuhel, R. L.: The cycling of sulfur in surface seawater of the northeast Pacific, J. Geophys. Res., 99, 7835-7843, 1994.

Baumann, M. E. M., Brandini, F. P., and Staubes, R.: The influence of light and temperature on carbon-specific DMS release by cultures of Phaeocystis-Antarctica and 3 antarctic Diatoms, Marine Chemistry, 45, 129-136, 1994.

Belviso, S., Bopp, L., Moulin, C., Orr, J. C., Anderson, T. R., Aumont, O., Chu, S., Elliott, S., Maltrud, M., and Simó, R.: Comparison of Global Climatological Maps of Sea Surface Dimethyl Sulfide, Global Biogeochem. Cycles, 18, doi:10.1029/2003GB002193, 2004a.

Belviso, S., Moulin, C., Bopp, L., and Stefels, J.: Assessment of a global climatology of oceanic Dimethylsulfide (DMS) concentrations based on SeaWIFS imagery (1998-2001), Canadian J. of Fisheries and Aquatic Sciences, 61, 804-816, 2004b.

Berglen, T. F., Berntsen, T. K., Isaksen, I. S. A., and Sundet, J. K.: A global model of the coupled sulfur/oxidant chemistry in the troposphere: The sulfur cycle, J. Geophys. Res., 109, doi:10.1029/2003JD003948, 2004.

Berresheim, H., Eisele, F. L., Tanner, D. J., McInnes, L. M., Ramseybell, D. C., and Covert, D. S.: Atmospheric sulfur chemistry and Cloud Condensation Nuclei $(\mathrm{CCN})$ concentrations over the northeastern Pacific coast, J. Geophys. Res., 98, 12 701-12 711, 1993

Bond, T. C., Streets, D. G., Yarber, K. F., Nelson, S. M., Woo, J. H., and Klimont, Z.: A technology-based global inventory of black and organic carbon emissions from combustion, J. Geophys. Res., 109, doi:10.1029/2003JD003697, 2004.

Boucher, O. and Pham, M.: History of sulfate aerosol radiative forcings, Geophys. Res. Lett., 29, doi:10.1029/2001GL014048, 2002.

Boucher, O., Moulin, C., Belviso, S., Aumont, O., Bopp, L., Cosme, E., von Kuhlmann, R., Lawrence, M. G., Pham, M., Reddy, M. S., Sciare, J., and Venkataraman, C.: DMS atmospheric concentrations and sulphate aerosol indirect radiative forcing: A sensitivity study to the DMS source representation and oxidation, Atmos. Chem. Phys., 3, 49-65, 2003.

SRef-ID: 1680-7324/acp/2003-3-49.

Brimblecombe, P. and Shooter, D.: Photooxidation of Dimethylsulfide in aqueous-solution, Marine Chemistry, 19, 343-353, 1986.

Campolongo, F., Saltelli, A., Jensen, N. R., Wilson, J., and Hjorth, J.: The role of multiphase chemistry in the oxidation of Dimethylsulphide (DMS). A latitude dependent analysis, J. Atmos. Chem., 32, 327-356, 1999.

Capaldo, K. P. and Pandis, S. N.: Dimethylsulfide chemistry in the remote marine atmosphere: Evaluation and sensitivity analysis of available mechanisms, J. Geophys. Res., 102, 23 251-23 267, 1997.
Charlson, R. J., Lovelock, J. E., Andreae, M. O., and Warren., S. G.: Oceanic phytoplankton, atmospheric sulfur, cloud albedo and climate, Nature, 326, 655-661, 1987.

Chin, M., Rood, R. B., Lin, S., Müller, J. F., and Thompson, A. M.: Atmospheric sulfur cycle simulated in the global model GOCART: Model description and global properties, J. Geophys. Res., 105, 24 671-24 687, 2000.

Chu, S. P., Elliott, S., and Maltrud, M. E.: Global eddy permitting simulations of surface ocean nitrogen, iron, sulfur cycling, Chemosphere, 50, 223-235, 2003.

Cofala, J., Amann, M., and Mechler, R.: Scenarios of world anthropogenic emissions of air pollutants and methane up to 2030, Tech. rep., International Institute for Applied Systems Analysis (IIASA), Laxenburg, Austria, available from: http://www.iiasa. ac.at/rains/global_emiss/global_emiss.html, 2005.

Dacey, J. W. H. and Wakeham, S. G.: Oceanic Dimethylsulfide production during zooplankton grazing on phytoplankton, Science, 233, 1314-1316, 1986.

Feichter, J., Kjellstrom, E., Rodhe, H., Dentener, F., Lelieveld, J., and Roelofs, G. J.: Simulation of the tropospheric sulfur cycle in a global climate model, Atmos. Environ., 30, 1693-1707, 1996.

Fouquart, Y. and Bonnel, B.: Computations of solar heating of the Earth's atmosphere: A new parameterization. A prognostic parameterization for the subgrid-scale variability of water vapor and clouds in large-scale models and its use to diagnose cloud cover, Beitr. Phys. Atmos., 59, 35-62, 1980.

Fung, I. Y., Meyn, S. K., Tegen, I., Doney, S. C., John, J., and Bishop, J.: Iron supply and demand in the upper ocean, Global Biogeochem. Cycles, 14, 697-700, 2000.

Gabric, A., Murray, N., Stone, L., and Kohl, M.: Modeling the production of Dimethylsulfide during a phytoplankton bloom, J. Geophys. Res., 98, 22 805-22 816, 1993.

Gabric, A. J., Gregg, W., Najjar, R., Erickson, D., and Matrai, P. Modeling the biogeochemical cycle of Dimethylsulfide in the upper ocean: A review, Chemosphere, 3, 377-392, 2001.

Ganzeveld, L., Lelieveld, J., and Roelofs, G.: A dry deposition parameterization for sulfur oxides in a chemistry and general circulation model, J. Geophys. Res., 103, 5679-5694, 1998.

Gent, P. R., Willebrand, J., McDougall, T. J., and McWilliams, J. C.: Parameterizing eddy-induced tracer transports in ocean circulation models, J. Phys. Oceanogr., 25, 463-474, 1995.

Gondwe, M., Krol, M., Gieskes, W., Klaassen, W., and de Baar, H.: The contribution of ocean-leaving DMS to the global atmospheric burdens of DMS, MSA, SO2, and nss SO4=, Global Biogeochem. Cycles, 17, doi:10.1029/2002GB001937, 2003.

Gong, S. L. and Barrie, L. A.: Simulating the impact of sea salt on global nss sulphate aerosols, J. Geophys. Res., 108, doi:10.1029/2002JD003181, 2003.

Guenther, A., Hewitt, C. N., Erickson, D., Fall, R., Geron, C., Graedel, T., P. Harley, P., Klinger, L., Lerdau, M., McKay, W. A., Pierce, T., Scholes, B., Steinbrecher, R., Tallamraju, R., Taylor, J., and Zimmerman, P.: A global-model of natural volatile organic-compound emissions, J. Geophys. Res., 100, 8873-8892, 1995

Halmer, M. M., Schmincke, H., and Graf, H. F.: The annual volcanic gas input into the atmosphere, in particular into the stratosphere: A global data set for the past 100 years, J. Volcanology and Geothermal Res., 115, 511-528, 2002. 
Hibler, W. D.: Dynamic thermodynamic sea ice model, J. Phys. Oceanogr., 9, 815-846, 1979.

Horowitz, L. W., Walters, S., Mauzerall, D. L., Emmons, L. K., Rasch, P. J., Granier, C., Tie, X. X., Lamarque, J. F., Schultz, M. G., Tyndall, G. S., Orlando, J. J., and Brasseur, G. P.: A global simulation of tropospheric ozone and related tracers: Description and evaluation of MOZART, Version 2, J. Geophys. Res., 108, doi:10.1029/2002JD002853, 2003.

Jones, A., Roberts., D. L., Woodage, M. J., and Johnson, C. E.: Indirect sulphate aerosol forcing in a climate model with an interactive sulphur cycle, J. Geophys. Res., 106, 20 293-20310, 2001.

Kalnay, E., Kanamitsu, M., Kistler, R., Collins, W., Deaven, D., Gandin, L., Iredell, M., Saha, S., White, G., Woollen, J., Zhu, Y., Chelliah, M., Ebisuzaki, W., Higgins, W., Janowiak, J., Mo, K. C., Ropelewski, C., Wang, J., Leetmaa, A., Reynolds, R., Jenne, R., and Joseph, D.: The NCEP/NCAR 40-Year Reanalysis Project, Bull. Meteor. Soc., 77, 437-471, 1996.

Keller, M., Bellows, W., and Guillard, R.: Dimethyl sulfide production in marine phytoplankton, in: Biogenic sulfur in the enviroment, edited by: Saltzman, E. and Cooper, W., ACS-Symposium series, p. 167-181, New Orleans, Louisiana, 1989.

Kettle, A. J. and Andreae, M. O.: Flux of Dimethylsulfide from the oceans: A comparison of updated data sets and flux models, J. Geophys. Res., 105, 26 793-26 808, 2000.

Kettle, A. J., Andreae, M. O., Amouroux, D., Andreae, T. W., Bates, T. S., Berresheim, H., Bingemer, H., Boniforti, R., Curran, M. A. J., Ditullio, G. R., Helas, G., Jones, G. B., Keller, M. D., Kiene, R. P., Leck, C., Levasseur, M., Malin, G., Maspero, M., Matrai, P., McTaggart, A. R., Mihalopoulos, N., Nguyen, B. C., Novo, A., Putaud, J. P., Rapsomanikis, S., Roberts, G., Schebeske, G., Sharma, S., Simó, R., Staubes, R., Turner, S., and Uher, G.: A global database of sea surface Dimethylsulfide (DMS) measurements and a procedure to predict sea surface DMS as a function of latitude, longitude, and month, Global Biogeochem. Cycles, 13, 399-444, 1999.

Kieber, D. J., Jiao, J. F., Kiene, R. P., and Bates, T. S.: Impact of Dimethylsulfide photochemistry on methyl sulfur cycling in the equatorial Pacific Ocean, J. Geophys. Res., 101, 3715-3722, 1996.

Kiene, R. P.: Production of methanethiol from Dimethylsulfonioproponiate in marine surface waters, Mar. Chem., 54, 69-83, 1996.

Kiene, R. P. and Bates, T. S.: Biological removal of Dimethyl Sulfide from sea-water, Nature, 345, 702-705, 1990.

Kiene, R. P., Linn, L. J., and Bruton, J. A.: New and important roles for DMSP in marine microbial communities, J. Sea Res., 43, 209-224, 2000.

Kirst, G. O., Thiel, C., Wolff, H., Nothnagel, J., Wanzek, M., and Ulmke, R.: Dimethylsulfoniopropionate (DMSP) in ice-algae and its possible biological role, Marine Chemistry, 35, 381-388, 1991.

Koch, D., Jacob, D., Tegen, I., Rind, D., and Chin, M.: Tropospheric sulfur simulation and sulfate direct radiative forcing in the Goddard Institute for Space Studies General Circulation Model, J. Geophys. Res., 104, 23 799-23 822, 1999.

Kwint, R. L. J. and Kramer, K. J. M.: Dimethylsulfide production by plankton communities, Marine Ecology-Progress Series, 121, 227-237, 1995.
Lin, S. J. and Rood, R. B.: Multidimensional flux-form semilagrangian transport schemes, Mon. Weather Rev., 124, 20462070, 1996.

Liss, P. S. and Merlivat, L.: Air-Sea exchange rates: introduction and synthesis, in The Role of Air-Sea Exchange in Geochemical Cycling, edited by P. Buat-Menard, pp. 113-127, NATO ASI Series Series C: Mathematical and physical science, 1986.

Liss, P. S., Hatton, A. D., Malin, G., Nightingale, P. D., and Turner, S. M.: Marine sulphur emissions, Philosophical Transactions: Biological Science, 352, 159-168, 1997.

Lohmann, U. and Roeckner, E.: Design and performance of a new cloud microphysics scheme developed for the ECHAM general circulation model, Clim. Dynam., 12, 557-572, 1996.

Lovelock, J. E., Maggs, R. J., and Rasmusse, R. A.: Atmospheric Dimethyl Sulfide and natural sulfur cycle, Nature, 237, 452-453, 1972.

Maier-Reimer, E.: Geochemical cycles in an ocean circulation model: Preindustrial tracer distributions, Global Biogeochem. Cycles, 7, 645-677, 1993.

Maier-Reimer, E., Kriest, I., Segschneider, J., and Wetzel, P.: The Hamburg Ocean Carbon Cycle Model HAMOCC5.1 - Technical Description Release 1.1, Report on Earth System Science, 14, Max Planck Institute for Meteorology, Hamburg, Germany, available from http://www.mpimet.mpg.de., 2005.

Malin, G., Wilson, W. H., Bratbak, G., Liss, P. S., and Mann, N. H.: Elevated production of Dimethylsulfide resulting from viral infection of cultures of Phaeocystis Pouchetii, Limnol. Oceanogr., 43, 1389-1393, 1998.

Marsland, S. J., Haak, H., Jungclaus, J. H., Latif, M., and Roske, F.: The Max-Planck-Institute global ocean/sea ice model with orthogonal curvilinear coordinates, Ocean Modelling, 5, 91-127, 2003.

McGillis, W. R., Dacey, J. W. H., Frew, N. M., Bock, E. J., and Nelson, R. K.: Water-air flux of Dimethylsulfide, J. Geophys. Res., 105, 1187-1193, 2000.

Morcrette, J. J., Clough, S. A., Mlawer, E. J., and Iacono, M. J.: Impact of a validated radiative transfer scheme, RRTM, on the ECMWF model climate and 10-day forecasts, Technical Memorandum 252, ECMWF, Reading, UK., 1998.

Nguyen, B. C., Mihalopoulos, N., and Belviso, S.: Seasonalvariation of atmospheric Dimethylsulfide at Amsterdam Island in the southern Indian-Ocean, J. Atmos. Chem., 11, 123-141, 1990.

Nightingale, P. D., Malin, G., Law, C. S., Watson, A. J., Liss, P. S., Liddicoat, M. I., Boutin, J., and Upstill-Goddard, R. C.: In situ evaluation of air-sea gas exchange parameterizations using novel conservative and volatile tracers, Global Biogeochem. Cycles, 14, 373-387, 2000.

Nordeng, T. E.: Extended versions of the convective parameterization scheme at ECMWF and their impact on the mean and transient activity of the model in the tropics. Technical Memorandum 206, ECMWF, Reading, UK., 1994.

O’Dowd, C. D., Lowe, J. A., Smith, M. H., and Kaye, A. D.: The relative importance of non-sea-salt sulphate and sea-salt aerosol to the marine cloud condensation nuclei population: An improved multi-component aerosol-cloud droplet parametrization, Quart. J. Roy. Meteorol. Soc., 125, 1295-1313, 1999. 
Oschlies, A.: Model-derived estimates of new production: New results point towards lower values, Deep-Sea Res., Part B, pp. 2173-2197, 2002.

Penner, J. E., Andreae, M., Annegram, H., Barrie, L., Feichter, J., Hegg, D., Jayaraman, A., Leaitch, R., Murphy, D., Nganga, J., and Pitari, G.: Aerosols, their direct and indirect effects, in Climate Change 2001: The Scientific basis, Cambridge University Press, p. 289-348, J. T. Houghton, 2001.

Pham, M., Müller, J. F., Brasseur, G. P., Granier, C., and Megie, G.: A three-dimensional study of the tropospheric sulfur cycle, J. Geophys. Res., 100, 26 061-26092, 1995.

Putaud, J. P., Mihalopoulos, N., Nguyen, B. C., Campin, J. M., and Belviso, S.: Seasonal-variations of atmospheric sulfur-dioxide and Dimethylsulfide concentrations at Amsterdam Island in the southern Indian-Ocean, J. Atmos. Chem., 15, 117-131, 1992.

Putaud, J. P., Belviso, S., Nguyen, B. C., and Mihalopoulos, N.: Dimethylsulfide, aerosols, and condensation nuclei over the tropical northeastern Atlantic-Ocean, J. Geophys. Res., 98, 14 863$14871,1993$.

Roeckner, E., Baeuml, G., Bonventura, L., Brokopf, R., Esch, M., Giorgetta, M., Hagemann, S., Kirchner, I., Kornblueh, L., Manizini, E., Rhodin, A., Schlese, U., Schulzweida, U., and Tompkins, A.: The atmospheric general circulation model ECHAM5. Part I: Model description, Report 349, Max Planck Institute for Meteorology, Hamburg, Germany, available from: http://www. mpimet.mpg.de, 2003.

Rotstayn, L. D. and Lohmann, U.: Simulation of the tropospheric sulfur cycle in a global model with a physically based cloud scheme, J. Geophys. Res., 107, doi:10.1029/2002JD002128, 2002.

Saltzman, E. S., King, D. B., Holmen, K., and Leck, C.: Experimental-determination of the diffusion-coefficient of Dimethylsulfide in water, J. Geophys. Res., 98, 16481-16486, 1993.

Sarmiento, J. L., Dunne, J., Gnanadesikan, A., Key, R. M., Matsumoto, K., and Slater, R.: A new estimate of the $\mathrm{CaCO}_{3}$ to organic carbon export ratio, Global Biogeochemical Cycles, 16, doi:10.1029/2002GB001919, 2002.

Sayin, H. and McKee, M. L.: Computational study of the reactions between $\mathrm{XO}(\mathrm{X}=\mathrm{Cl}, \mathrm{Br}, \mathrm{I})$ and Dimethyl Sulfide, J. Phys. Chem., 108, 7613-7620, 2004.

Schulz, M., de Leeuw, G., and Balkanski, Y.: Sea salt aerosol source functions and emissions, in: Emission of atmospheric trace compounds, edited by: Granier, C., Artaxo, P., and Reeves, C., 2004.

Sciare, J., Mihalopoulos, N., and Dentener, F. J.: Interannual variability of atmospheric Dimethylsulfide in the Southern Indian Ocean, J. Geophys. Res., 105, 26369-26 377, 2000.

Shooter, D. and Brimblecombe, P.: Dimethylsulfide oxidation in the ocean, Deep-Sea Res., Part A, 36, 577-585, 1989.

Simó, R. and Dachs, J.: Global ocean emission of Dimethylsulfide predicted from biogeophysical data, Global Biogeochem. Cycles, 16, doi:10.1029/2001GB001829, 2002.

Simó, R. and Pedrós-Alió, C.: Role of vertical mixing in controlling the oceanic production of Dimethyl Sulphide, Nature, 402, 396$398,1999$.

Six, K. D. and Maier-Reimer, E.: Effects of plankton dynamics on seasonal carbon fluxes in a ocean general circulation model, Global Biogeochem. Cycles, 10, 559-583, 1996.

Stefels, J.: Physiological aspects of the production and conversion of DMSP in marine algae and higher plants, J. Sea Res., 43, 183 197, 2000.

Steinke, M., Malin, G., Archer, S. D., and Burkill, P. H.: Vertical and temporal variability of DMSP lyase activity in a coccolithophorid bloom in the northern North Sea, Deep-Sea Res., Part B, 49, 3001-3016, 2002.

Stier, P., Feichter, J., Kloster, S., Vignati, E., and Wilson, J.: Emission-Induced Nonlinearities in the Global Aerosol System - Results From the ECHAM5-HAM Aerosol-Climate Model, J. Clim., accepted, 2004.

Stier, P., Feichter, J., Kinne, S., Kloster, S., Vignati, E., Wilson, J., Ganzeveld, L., Tegen, I., Werner, M., Balkanski, Y., Schulz, M., Boucher, O., Minikin, A., and Petzold, A.: The aerosolclimate model ECHAM5-HAM, Atmos. Chem. Phys., 5, 11251156, 2005,

SRef-ID: 1680-7324/acp/2005-5-1125.

Suda, W., Kieber, D. J., Kiene, R. P., and Huntsman, S.: An antioxidant function for DMSP and DMS in marine algae, Nature, 418, 317-320, 2002.

Sweby, P. K.: High-resolution schemes using flux limiters for hyperbolic conservation-laws, Siam Journal On Numerical Analysis, 21, 995-1011, 1984.

Tegen, I., Harrison, S. P., Kohfeld, K., Prentice, I. C., Coe, M., and Heimann, M.: Impact of vegetation and preferential source areas on global dust aerosol: Results from a model study, J. Geophys. Res., 107, doi:10.1029/2001JD000963, 2002.

Tegen, I., Werner, M., Harrison, S. P., and Kohfeld, K. E.: Relative importance of climate and land use in determining present and future global soil dust emission, Geophys. Res. Lett., 31, doi:10.1029/2003GL019216, 2004.

Tiedtke, M.: A comprehensive mass flux scheme for cumulus parameterization in large-scale models, Mon. Weather Rev., 117, 1779-1800, 1989.

Tompkins, A. M.: A prognostic parameterization for the subgridscale variability of water vapor and clouds in large-scale models and its use to diagnose cloud cover, J. Atmos. Sci., 59, 19171942, 2002.

Vairavamurthy, A., Andreae, M. O., and Iverson, R. L.: Biosynthesis of Dimethylsulfide and Dimethylpropiothetin by Hymenomonas-Carterae in relation to sulfur source and salinity variations, Limnol. Oceanogr., 30, 59-70, 1985.

Valcke, S., Caubel, A., Declat, D., and Terray, L.: OASIS ocean atmosphere sea ice soil users's guide, Technical Report, TR/CMGC/03/69, CERFACS, Toulouse, France, 2003.

van der Werf, G. R., Randerson, J. T., Collatz, G. J., and Giglio, L.: Carbon emissions from fires in tropical and subtropical ecosystems, Global Change Biology, 9, 547-562, 2003.

Vézina, A. F.: Ecosystem modelling of the cycling of marine dimethylsulfide: A review of current approaches and of the potential for extrapolation on global scales, Canadian J. of Fisheries and Aquatic Sciences, 61, 845-856, 2004.

Vignati, E., Wilson, J., and Stier, P.: M7: An efficient size-resolved aerosol microphysics module for large-scale aerosol transport models, J. Geophys. Res., 109, doi:10.1029/2003JD004485, 2004.

von Glasow, R. and Crutzen, P. J.: Model study of multiphase DMS oxidation with a focus on halogens, Atmos. Chem. Phys., 4, 589608, 2004,

SRef-ID: 1680-7324/acp/2004-4-589. 
Wanninkhof, R.: Relationship between wind-speed and gasexchange over the ocean, J. Geophys. Res., 97, 7373-7382, 1992.

Wanninkhof, R. and McGillis, W. R.: A cubic relationship between air-sea $\mathrm{CO}_{2}$ exchange and wind speed, Geophys. Res. Lett., 26, 1889-1892, 1999.

Wetzel, P.: Interannual and Decadal Variability in the Air-Sea Exchange of $\mathrm{CO}_{2}$ - A Model Study, Report on Earth System Science, 7, Max Planck Institute for Meteorology, Hamburg, Germany, available from: http://www.mpimet.mpg.de, 2004.

Wetzel, P., Winguth, A., and Maier-Reimer, E.: Sea-To-Air $\mathrm{CO}_{2}$ flux from 1948 to 2003: A model study, Global Biogeochem. Cycles, 19, doi:10.1029/2004GB002339, 2005.

Yin, F. D., Grosjean, D., and Seinfeld, J. H.: Photooxidation of Dimethyl Sulfide and Dimethyl Disulfide. 1: Mechanism development, J. Atmos. Chem., 11, 309-364, 1990.
Yoch, D. C., Ansede, J. H., and Rabinowitz, K. S.: Evidence for intracellular and extracellular Dimethylsulfonioproponiate (DMSP) lyases and DMSP uptake site in two species of marine bacteria, Appl. Environ. Microbiol., 63, 3182-3188, 1997.

Yoon, Y. J. and Brimblecombe, P.: Modelling the contribution of sea salt and Dimethyl Sulfide derived aerosol to marine CCN, Atmos. Chem. Phys., 2, 17-30, 2002,

SRef-ID: 1680-7324/acp/2002-2-17.

Zemmelink, H. J., Gieskes, W. W. C., Klaassen, W., de Groot, H. W., de Baar, H. J. W., Dacey, J. W. H., Hintsa, E. J., and McGillis, W. R.: Simultaneous use of relaxed eddy accumulation and gradient flux techniques for the measurement of sea-toair exchange of Dimethyl Sulphide, Atmos. Environ., 36, 5709$5717,2002$. 